\title{
Epidermal Growth Factor Receptor Expression and Resistance Patterns to Targeted Therapy in Non-Small Cell Lung Cancer: A Review
}

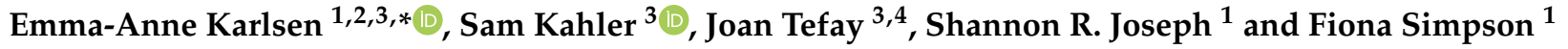 \\ 1 Simpson Laboratory, The University of Queensland Diamantina Institute, Woolloongabba, \\ Brisbane 4102, Australia; s.joseph@uq.edu.au (S.R.J.); f.simpson@uq.edu.au (F.S.) \\ 2 Department of General Surgery, Mater Hospital Brisbane, South Brisbane 4101, Australia \\ 3 Faculty of Medicine, The University of Queensland, St Lucia 4067, Australia; samkahler96@gmail.com (S.K.); \\ joan.tefay@gmail.com (J.T.) \\ 4 Department of General Surgery, Redland Hospital, Cleveland 4163, Australia \\ * Correspondence: e.karlsen@uq.edu.au
}

Citation: Karlsen, E.-A.; Kahler, S.;

Tefay, J.; Joseph, S.R.; Simpson, F.

Epidermal Growth Factor Receptor

Expression and Resistance Patterns to

Targeted Therapy in Non-Small Cell

Lung Cancer: A Review. Cells 2021,

10, 1206. https://doi.org/

$10.3390 /$ cells10051206

Academic Editor: Silvia La Monica

Received: 19 April 2021

Accepted: 6 May 2021

Published: 14 May 2021

Publisher's Note: MDPI stays neutral with regard to jurisdictional claims in published maps and institutional affiliations.

Copyright: (c) 2021 by the authors. Licensee MDPI, Basel, Switzerland. This article is an open access article distributed under the terms and conditions of the Creative Commons Attribution (CC BY) license (https:/ / creativecommons.org/licenses/by/ $4.0 /)$.

\begin{abstract}
Globally, lung cancer is the leading cause of cancer-related death. The majority of non-small cell lung cancer (NSCLC) tumours express epidermal growth factor receptor (EGFR), which allows for precise and targeted therapy in these patients. The dysregulation of EGFR in solid epithelial cancers has two distinct mechanisms: either a kinase-activating mutation in EGFR (EGFR-mutant) and/or an overexpression of wild-type EGFR (wt-EGFR). The underlying mechanism of EGFR dysregulation influences the efficacy of anti-EGFR therapy as well as the nature of resistance patterns and secondary mutations. This review will critically analyse the mechanisms of EGFR expression in NSCLC, its relevance to currently approved targeted treatment options, and the complex nature of secondary mutations and intrinsic and acquired resistance patterns in NSCLC.
\end{abstract}

Keywords: epidermal growth factor receptor; non-small cell lung cancer; drug resistance; tyrosine kinase inhibitor; monoclonal antibody

\section{Introduction}

Lung cancer is the leading cause of cancer-related mortality amongst both men and women, accounting for approximately $25 \%$ of all cancer deaths globally [1]. There are two main forms of lung cancer: non-small cell lung cancer (NSCLC) and small cell lung cancer (SCLC), which account for $85 \%$ and $15 \%$ of diagnoses, respectively [2]. The World Health Organisation has subclassified NSCLC into three main types: adenocarcinoma, squamous cell carcinoma, and large cell $[3,4]$. Adenocarcinoma is the most common type of NSCLC, accounting for approximately $40 \%$ of lung cancers [3]. Although tobacco smoking is a major risk factor for lung cancer, approximately $10-25 \%$ of all lung cancers occur in nonsmokers [5]. In non-smokers, carcinogenesis is linked to the presence of distinct oncogenic driver mutations, including epidermal growth factor receptor (EGFR), proto-oncogene B-Raf (BRAF), MET proto-oncogene (MET), and Kirsten rat sarcoma viral oncogene (KRAS) [6].

EGFR was the first oncogenic target discovered in NSCLC and is present in over $60 \%$ of patients [7-9]. The presence of activating EGFR mutations is associated with female gender and adenocarcinoma histology and inversely associated with smoking history [10]. EGFR is a commonly altered oncogene in other solid epithelial cancers, such as colorectal cancer, head and neck cancer, pancreatic cancer, breast cancer, and glioblastoma [11]. However, two distinguishable mechanisms exist between these cancers: either a kinase-activating mutation in EGFR (EGFR-mutant) or an overexpression of the EGFR protein (wt-EGFR). Kinase-activating mutations lead to increased tyrosine kinase activity in EGFR and are frequently present in NSCLC and glioblastoma but rarely in 
other types of cancers (Table 1) [7,8,12-14]. Overexpression of wt-EGFR protein can be present with or without underlying EGFR gene amplifications and is often associated with a negative prognosis [15-22]. The underlying mechanism behind EGFR-positive cancers, whether it be mutations, gene amplification, or overexpression, has a significant impact on the efficacy of anti-EGFR therapies and resistance patterns.

\section{EGFR Molecular Biology}

Receptor Structure and Activation

The EGFR belongs to the ErbB family of tyrosine kinase receptors, which comprises four family members: EGFR/HER1/erbB1, HER2/erbB2/neu, HER3/erb3, and HER4/erb4 [23]. Each family member has an extracellular domain (ECD) with two cysteinerich regions, a single transmembrane or membrane-spanning region, a juxtamembrane cytoplasmic domain, and an intracellular kinase (or pseudokinase domain) with multiple C-terminal tyrosine residues that are phosphorylated on ligand binding and receptor activation [24,25]. There are crucial structural and functional differences between the ErbB receptor family members. In particular, ErbB3 lacks kinase activity due to the substitution of amino acids in the kinase domain, while ErbB2 has no known ligand binding capacity [26]. This has significant implications in receptor activation and subsequent intracellular signalling.

Growth factors that bind to ErbB receptors belong to the EGF-family and are typically secreted in an autocrine and paracrine fashion [27]. The binding of growth factors to ErbB receptors induces dimerisation via interactions between the extracellular region [27]. Although all forms of dimerisation between the ErbB receptors are possible, not all are biologically significant [27]. Ligand binding to EGFR induces homodimerisation, as well as heterodimerisation with ErbB2, ErbB3 and ErbB4 receptors [28]. ErbB2 receptor is only activated when heterodimerisation occurs with another ErbB receptor [24]. Heterodimerisation also serves to increase the repertoire of intracellular signalling pathways utilised for downstream effects [28].

EGFR is located on chromosome 7 short arm q22 [28]. Mature EGFR contains 1186 residues and is formed when a 1210 residue-containing precursor is cleaved at the Nterminal [29]. The extracellular domain of EGFR is made of 621 amino acids and comprises four subdomains, I (large EGF binding domain 1 (L1), amino acids 1-333, exons 1-4), II (cysteine-rich domain 1 (CR1), amino acids 134-152, exons 5-7), III (large EGF binding domain 2 (L2), amino acids 313-445, exons 8-12), and IV (cysteine-rich domain 2 (CR2), amino acids 446-621, exons 13-16) [26,29] (Figure 1). The transmembrane region is a single 23 -amino acid long hydrophobic $\alpha$-helical peptide. The tyrosine kinase domain is made of conserved amino acids 690-953 (exons 18-24) and is divided into an N-lobe and a C-lobe (Figure 1). Between the two lobes lies the adenosine triphosphate (ATP)-binding site for phosphorylation [26,29]. Finally, the C-terminal fragment rich in tyrosine residues (amino acids 954-1136, exons 25-28) enables coupling with intracellular signalling proteins [29].

Six ligands (EGF, transforming growth factor alpha (TGF $\alpha$ ), amphiregulin, betacellulin, heregulin, and heparin-binding EGF) are known to bind to EGFR. [30]. These ligands interact with two (I and III) of four subdomains rich in cysteine residues that comprise the extracellular domain of ErbB receptors [27,28]. Subdomain II contains a beta hairpin (also called a dimerisation loop) that facilitates homo/heterodimerisation. This brings into proximity the cytoplasmic kinase domains, which facilitate the activation of the cytoplasmic component through both phosphorylation-dependent and nondependent mechanisms [23,31]. This subsequently enables coupling with intracellular downstream signalling molecules containing Src homology 2 (SH2) and phosphotyrosine binding (PTB) domains $[27,28]$.

Three main signalling pathways are activated downstream of EGFR: the Ras/Raf/ Mitogen-activated protein kinases (MAPK) pathway, the phosphatidylinositol 3-kinase (PI3K) / AKT8 virus oncogene cellular homolog the (AKT)/Mammalian target of rapamycin (mTOR) pathway and the signal transducer and activator of the transcription (STAT) 
pathway $[9,28]$. In the first pathway, adaptor protein Grb2 containing SH2 domain binds to activated EGFR and interacts with and activates Ras [28]. This in turn activates Raf-1, and the downstream pathway leads to nuclear transcription factor activation via extracellular signal-regulated kinases (ERK)-1 and ERK-2 MAP kinases [28]. The Ras/Raf/MAPK pathway is involved in cell proliferation, survival, migration, and angiogenesis.

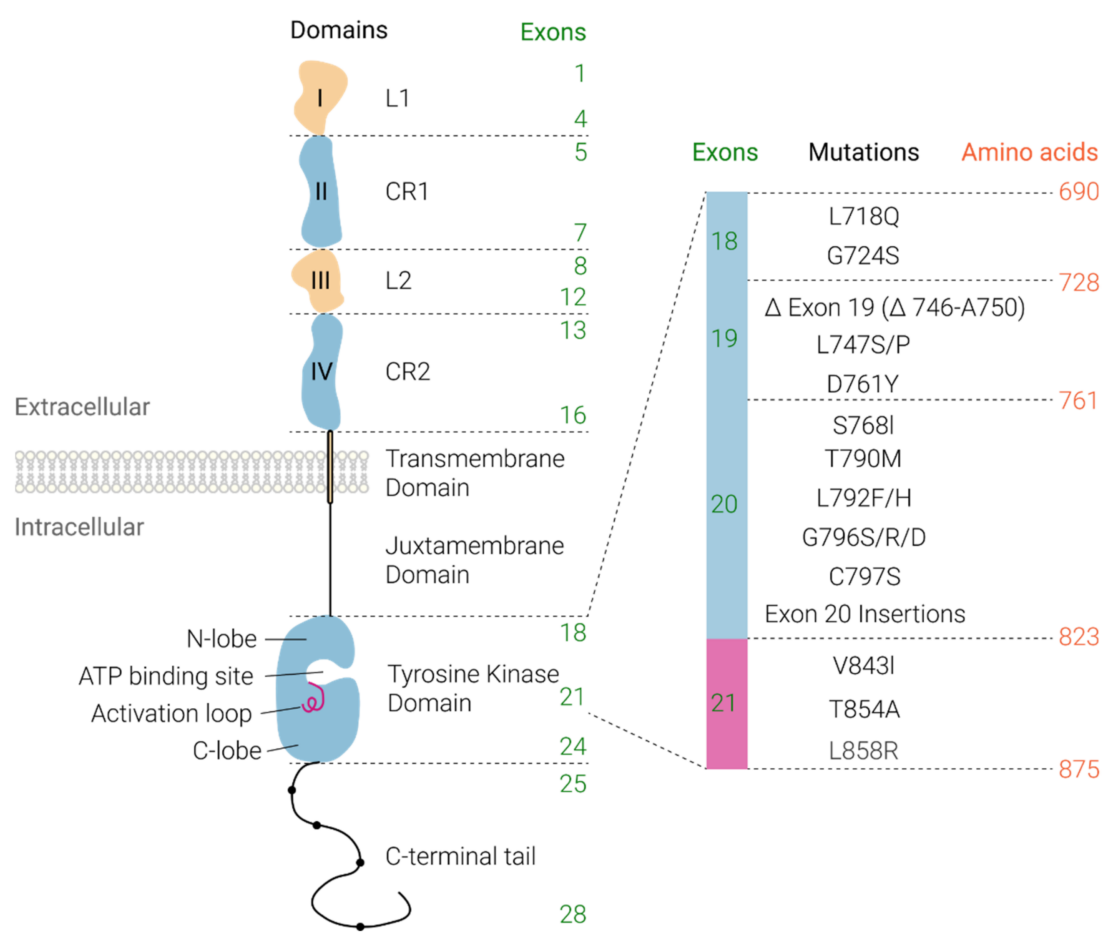

Figure 1. A schematic representation of EGFR illustrating exon boundaries and associated extracellular, transmembrane, and intracellular protein domains. The extracellular domain is involved in ligand binding (Domains I and III) and dimerisation (Domain II). The intracellular domain contains a juxtamembrane domain, tyrosine kinase domain, and multiple C-terminal tyrosine residues (circles), which are phosphorylated on ligand binding and receptor activation leading to the activation of cell proliferation, survival, migration, and/or angiogenesis signalling pathways. The tyrosine kinase domain is expanded to show relevant mutations associated with resistance and sensitivity to first-, second- and third-generation tyrosine kinase inhibitors as discussed in Table 3. (large EGF binding domain 1, L1; cysteine-rich domain 1, CR1; large EGF binding domain 2, L2; and cysteine-rich domain 1, CR2).

The PI3K/AKT/mTOR pathway is involved in cellular metabolism and motility $[28,29]$. PI3K interacts with EGFR via the adaptor protein Grb2-associated binding protein 1 (GAB1) and Ras. Activated PI3K recruits and activates AKT. Activated AKT regulates cell death in an antiapoptotic manner and also signals mTOR, which directly regulates cellular metabolism and cell growth [29].

The STAT pathway was first identified as part of the intracellular signalling pathway of cytokine receptors $[28,30]$. STAT binds to EGFR via the SH2 domain and is phosphorylated, leading to dimerisation. Activated STAT complexes translocate to the nucleus to regulate the transcription of genes involved in cellular proliferation, cell cycle progression, and apoptosis [30].

There are three main mechanisms leading to EGFR activation: increased EGFR expression in malignant cells, increased ligand production, and the presence of EGFR-activating mutations (Table 1) [32]. Although EGFR overexpression was originally thought to be a promising therapeutic focus, the specific targeting of activating mutations in cancers such as NSCLC has emerged as a superior therapeutic strategy. 
Table 1. Comparison of the incidence of EGFR-activating mutations and EGFR overexpression amongst common cancers.

\begin{tabular}{|c|c|c|c|c|c|c|}
\hline Cancer type & $\begin{array}{c}\text { Frequency of } \\
\text { Activating Mutations of EGFR }\end{array}$ & Study & $\begin{array}{c}\text { Frequency of } \\
\text { EGFR Overexpression }\end{array}$ & Sample Size & Method of Detection & Study \\
\hline \multirow{2}{*}{ NSCLC } & \multirow{2}{*}{$\begin{array}{c}50 \% \text { of Asian patients } \\
10-15 \% \text { of Caucasian } \\
\text { patients } \\
\end{array}$} & \multirow{2}{*}[33]{} & $43-89 \%$ & $96-515$ & $\mathrm{IHC}^{\mathrm{a}}$ & [34-43] \\
\hline & & & $31-58 \%$ & 2972 & Meta-analysis & [44] \\
\hline Colorectal carcinoma (CRC) & Rare $-2.33 \%$ & [45] & $51-75.5 \%$ & 99-193 & IHC & [46-49] \\
\hline \multirow[b]{2}{*}{ Head and neck SCC ${ }^{b}$} & \multirow[b]{2}{*}{ Rare- $1.72 \%$} & \multirow[b]{2}{*}[45]{} & $45 \%$ & 115 & IHC & [50] \\
\hline & & & $92 \%$ & 24 & $\begin{array}{l}\text { Southern blot } \\
\text { hybridisation }\end{array}$ & [51] \\
\hline $\begin{array}{c}\text { Pancreatic } \\
\text { adenocarcinoma }\end{array}$ & Rare- $-0.78 \%$ & [45] & $49-69 \%$ & $32-181$ & IHC & [52-54] \\
\hline Breast cancer & Rare-1.31\% & [45] & $27 \%$ & 21,418 & Meta-analysis & [55] \\
\hline Prostate & Rare- $-0.82 \%$ & [45] & $31-100 \%$ & $74-98$ & IHC & {$[56,57]$} \\
\hline Oesophageal SCC & Rare- $2.72 \%$ & [45] & $53.6-65 \%$ & $56-152$ & IHC & {$[58,59]$} \\
\hline Gastric & Rare $-2.2 \%$ & [45] & $27-44 \%$ & $82-511$ & IHC & {$[60,61]$} \\
\hline Hepatocellular carcinoma & Rare-1.59\% & {$[45]$} & $47-68 \%$ & $53-100$ & IHC & {$[62,63]$} \\
\hline Glioblastoma & $17.56 \%$ & [45] & $63 \%$ & 49 & IHC & [64] \\
\hline Ovary & Rare- $-0.98 \%$ & {$[45]$} & $28-33 \%$ & 80 & IHC & {$[65]$} \\
\hline Bladder & Rare- $3.28 \%$ & [45] & $26.2-71 \%$ & $72-126$ & IHC & {$[66,67]$} \\
\hline Renal cell carcinoma & Rare-1.16\% & [45] & $21-98 \%$ & 50-175 & IHC & [68-70] \\
\hline
\end{tabular}

\section{EGFR in NSCLC}

Dysregulated EGFR signalling is a well-established phenotype in NSCLC [26]. It can be caused by either overexpression or activating mutations [26]. Overexpression of EGFR is found to occur in approximately $60 \%$ of NSCLCs [26]. Additionally, molecular profiling studies have shown activating mutations in EGFR occur in 10-15\% of Caucasian patients and at least 50\% of Asian patients with NSCLC [71-73]. The evidence for a correlation between EGFR gene amplification and protein expression is conflicting, with several studies providing evidence both for and against the association [38,74-77].

The "classical" EGFR mutations consist of a deletion in exon 19 and a single amino acid substitution L858R in exon 21 and account for $47 \%$ and $41 \%$ of the EGFR mutations in NSCLC, respectively [78]. Rare mutations account for the remaining $12 \%$ and consist of point mutations, deletions, and insertions within exons 18-25 of the EGFR gene [79]. In general, these oncogenic mutations lead to a constitutive activation of the tyrosine kinase domain of EGFR (amino acids 690-952, exons 18-24) [29].

\section{EGFR-Targeted Therapy in NSCLC and Mechanisms of Resistance}

Anti-EGFR therapies consist of either monoclonal antibodies (mAbs) that are directed at the extracellular portion of the EGFR or small molecule tyrosine kinase inhibitors (TKIs) that target the intracellular protein kinase domain. Table 2 summarises the currently approved anti-EGFR therapies and their respective indications.

\subsection{Tyrosine Kinase Inhibitors (TKIs)}

TKIs inhibit receptor signalling by competitively blocking the binding of ATP to the cytoplasmic domain of the EGFR. These medications are associated with a high objective response rate, ranging from $50-77 \%$ [80-83]. In original studies, it was noted that certain characteristics, such as adenocarcinoma histology, Asian ethnicity, and minimal smoking history, were correlated with improved response to TKI therapy [71,84-91]. However, subsequent molecular testing of patients who had responded to TKIs demonstrated that somatic activating mutations in EGFR, were in fact underpinning the response $[33,86,87,92,93]$. 
Table 2. Currently approved anti-EGFR therapies and their indications.

\begin{tabular}{|c|c|c|}
\hline Cancer Type & Tyrosine Kinase Inhibitors & Monoclonal Antibodies \\
\hline NSCLC & $\begin{array}{c}\text { 1st generation } \\
\text { Gefitinib-metastatic NSCLC with EGFR exon } \\
19 \text { deletion or exon } 21 \text { mutation (L858R) } \\
\text { Erlotinib-metastatic or locally advanced NSCLC } \\
\text { with EGFR exon 19 deletion or exon } \\
\text { 21 mutation (L858R) } \\
\text { 2nd generation } \\
\text { Dacomitinib-metastatic NSCLC with EGFR exon } \\
19 \text { deletion or exon } 21 \text { mutation (L858R) } \\
\text { Afatinib-metastatic NSCLC with EGFR exon } \\
19 \text { deletion or exon } 21 \text { mutation (L858R) } \\
\text { 3rd generation } \\
\text { Osimertinib-metastatic EGFR T790M } \\
\text { mutation-positive NSCLC, with progressive } \\
\text { disease following first-line EGFR TKI therapy } \\
\text { Olmutinib-second-line treatment of NSCLC with } \\
\text { T790M mutation in EGFR }\end{array}$ & \\
\hline Pancreatic cancer & $\begin{array}{l}\text { Erlotinib-metastatic or advanced pancreatic } \\
\text { cancer in combination with gemcitabine }\end{array}$ & \\
\hline Breast cancer & $\begin{array}{l}\text { Neratinib-HER2-overexpressing breast cancer } \\
\text { Lapatinib-HER2-overexpressing breast cancer }\end{array}$ & \\
\hline Thyroid cancer & Vandetanib-medullary thyroid carcinoma & \\
\hline CRC & & $\begin{array}{c}\text { Cetuximab-metastatic KRAS-negative CRC; in } \\
\text { combination with chemotherapy or } \\
\text { as a single agent } \\
\text { Panitumumab-metastatic KRAS-negative CRC; } \\
\text { in combination with chemotherapy or as a } \\
\text { monotherapy in patients who } \\
\text { have failed chemotherapy }\end{array}$ \\
\hline Head and neck-SCC & & $\begin{array}{l}\text { Cetuximab-in combination with radiation } \\
\text { therapy for locally advanced disease or in } \\
\text { combination with chemotherapy for } \\
\text { recurrent/metastatic disease }\end{array}$ \\
\hline
\end{tabular}

The best characterised mutations that confer sensitivity to EGFR-TKI therapy are located in exon 19 (deletions, especially E746-A750del) and exon 21 (L858R) [92]. These classical mutations were investigated by Lynch et al. in 2004, who reported that EGFR mutations were related to the sensitivity of NSCLC to gefitinib, a first-generation TKI [93]. This work was supported by Paez et al. who demonstrated that these EGFR mutations were correlated with a clinical response to gefitinib [94]. EGFR TKIs are currently approved for the treatment of metastatic NSCLC with classical mutations (Table 2). Uncommon but pertinent EGFR mutations that confer sensitivity to TKI therapy include exon 18 point mutations (G719S/A/C) and exon 20 insertions (A763_Y64insFQEA) [92].

In patients with EGFR-mutant NSCLC, the Riesa Pan-Asia Study (IPASS) was the first to demonstrate a significant improvement in 12-month progression-free survival (PFS) with gefitinib, $24.9 \%$, compared to chemotherapy, $6.7 \%$ [95]. In contrast, patients with wt-EGFR had better outcomes with chemotherapy. This trial was subsequently supported by the First-SIGNAL study which demonstrated that, in patients treated with gefitinib, an EGFR-activating mutation predicted to have superior overall response rate (ORR) $(84.6 \%$ vs. $37.5 \%$ ) [96]. Several trials have compared the utility of gefitinib, erlotinib, or afatinib to chemotherapy specifically in patients with EGFR-mutant NSCLC [80-82,97-99]. All have demonstrated that first-line EGFR TKIs resulted in improved ORR, PFS, and quality of life 
compared to chemotherapy. This has formed the basis of TKIs being used as a first-line therapy in patients with EGFR-activating mutations.

The role of TKIs in patients with wt-EGFR NSCLC is controversial. Due to the results of the IPASS and TORCH trials, which demonstrated inferior survival compared to chemotherapy, first-line TKI therapy is not recommended in this population [84,95,100-103]. The TAILOR trial compared erlotinib to docetaxel specifically in wt-EGFR tumours and demonstrated significantly poorer ORR, PFS, and overall survival with the anti-EGFR therapy [104].

Consecutive analysis revealed that while $75 \%$ of patients with the common TKIsensitive L858R or 19del mutations respond to first-generation TKIs, an acquired resistance developed that limited PFS to less than 12 months [105-114]. The third-generation TKI, osimertinib, was developed to address the most common T790M-mediated resistance mechanism yet stable disease was limited to a PFS of 9.9 months [115]. Progression is understood to arise from clones with secondary EGFR mutations, enhanced signalling in a downstream or alternate pathway, histologic transformation, or mechanisms of transcriptional regulation (Table 3). Advances in understanding of these pathways and techniques to identify specific drivers of disease progression may allow the future development of adjunctive targeted therapies in the setting of acquired resistance. 
Table 3. Mechanisms of NSCLC resistance to TKI Therapy *

\begin{tabular}{|c|c|c|c|}
\hline Effector & Prevalence & Resistance To & Mechanism \\
\hline \multicolumn{4}{|c|}{ Germ Line Polymorphisms } \\
\hline EGFR-T790M & Preclinical [116] & 1st Gen. TKIs & $\begin{array}{l}\text { Allosteric hindrance of ATP-binding pocket, } \\
\text { increased ATP affinity }\end{array}$ \\
\hline EGFR-V843I & $3 / 5$ carriers developed disease [117] & 1st Gen. TKIs & $\begin{array}{c}\text { Steric hindrance, } \\
\text { associated with additional L858R mutation [118-120] }\end{array}$ \\
\hline BIM & $\begin{array}{l}\text { Deletion in } 12.9 \% \text { of East Asian } \\
\text { individuals [121] }\end{array}$ & 1st/2nd/3rd TKIs & $\begin{array}{l}\text { High BIM expression correlates with tumour apoptosis and } \\
\text { enhanced PFS/OS [122-127] }\end{array}$ \\
\hline \multicolumn{4}{|c|}{ Secondary EGFR Mutations } \\
\hline S768I & $9 / 1527$ cases & 1st Gen. TKIs & $\begin{array}{l}\text { Attenuated BIM to reduce apoptosis, } \\
\text { often with concurrent G719 or L858R }[123,128]\end{array}$ \\
\hline D761Y & $1 / 16$ cases & 1st Gen. TKIs & $\begin{array}{l}\text { Reduced EGFR phosphorylation with } \\
\text { additional L858R mutation }[129,130]\end{array}$ \\
\hline T854A & $1 / 48$ cases & 1st Gen. TKIs & Steric hindrance [131] \\
\hline L747S & $12 / 3648[132]$ & 1st Gen. TKIs & Steric hindrance [133] \\
\hline Exon20 Insertion & $\begin{array}{l}\text { Asia: } 67 / 218 \text { [136], } \\
\text { 23/186 Europe [137] }\end{array}$ & 1st/2nd/3rd Gen. TKIs & $\begin{array}{l}\text { Conformational change inducing constitutive } \\
\text { activation [136-139] }\end{array}$ \\
\hline L747P & Case Report & 1st/3rd Gen. TKIs & $\begin{array}{l}\text { Conformational change inducing constitutive } \\
\text { activation }[140,141]\end{array}$ \\
\hline T790M Amplification & Preclinical & 2nd Gen. TKIs & $\begin{array}{c}\text { Reversible selection of amplified clone in } \\
\text { response to TKI [142] }\end{array}$ \\
\hline C797S & $6 / 15$ cases [143] & 3rd Gen. TKIs & $\begin{array}{l}\text { Mutation in EGFR prevents osimertinib binding, } 84 \% \\
\text { co-occur with multiple resistance mechanisms [144] }\end{array}$ \\
\hline G796S/R/D & 23/93 cases & 1st/3rd Gen. TKIs & Steric hindrance $[145,146]$ \\
\hline $\mathrm{L} 792 \mathrm{~F} / \mathrm{H}$ & $10 / 93$ cases & 3rd Gen. TKIs & $\begin{array}{c}\text { Steric hindrance, arise in trans with T790M } \\
\text { and cis with C797S }[145,147]\end{array}$ \\
\hline L718Q & $9 / 93$ cases $[145,148]$ & 3rd Gen. TKIs & Steric hindrance [145] \\
\hline
\end{tabular}


Table 3. Cont.

\begin{tabular}{|c|c|c|c|}
\hline Effector & Prevalence & Resistance To & Mechanism \\
\hline G724S & $4 / 30$ cases & 3rd Gen. TKIs & $\begin{array}{l}\text { A glycine-rich loop conformation prevents initial } \\
\text { reversible TKI binding. The mutation is associated with } \\
\text { T790M loss, mutually exclusive to C979S, and } \\
\text { afatinib-sensitive }[149,150] \text {. }\end{array}$ \\
\hline \multicolumn{4}{|c|}{ Enhancement of Alternate Pathways } \\
\hline CRKL & $1 / 11$ cases $[151]$ & 1st/2nd Gen. TKIs & $\begin{array}{l}\text { Amplification, leading to downstream activation of ERK } \\
\text { and Akt }[151,152]\end{array}$ \\
\hline MAPK & Case report & 1st Gen. TKIs & ERK overexpression [153] \\
\hline IGF1R & Preclinical & 1st/2nd Gen. TKIs & Constitutive activation of PI3K/Akt pathway [154,155] \\
\hline MET & $\begin{array}{l}\text { 4/18 1st Gen-resistant cases [156], } \\
\text { 3/5 3rd Gen-resistant cases [157] }\end{array}$ & 1st/3rd Gen. TKIs [156-158] & HER3-dependent PI3K activation [156] \\
\hline HER2 & $\begin{array}{l}\text { 3/26 cases [159], } \\
\text { 2/5 3rd Gen-resistant cases [157] }\end{array}$ & 1st/2nd/3rd Gen. TKIs $[157,159]$ & $\begin{array}{l}\text { Alternative receptor amplification, } \\
\text { mutually exclusive with the T790M mutation [159] }\end{array}$ \\
\hline FGFR1 & $1 / 23$ cases $[160]$ & 3rd Gen. TKIs & Autocrine loop signalling [161] \\
\hline PTEN & $1 / 24$ cases & 1st/2nd Gen. TKIs & PI3K/Akt activation via PIK3CA [162] \\
\hline PIK3CA & $5 / 43$ cases $[163]$ & 1st/2nd/3rd Gen. TKIs & PI3K/Akt activation [164] \\
\hline AKT1 & $3 / 49$ cases & 1st/2nd/3rd Gen. TKIs & mTOR activation [165] \\
\hline BRAF & 2/195 cases & 3rd Gen. TKIs & MEK and ERK overexpression $[166,167]$ \\
\hline KRAS & $\begin{array}{l}3 / 43 \text { cases [167], } \\
\text { 9/38 adenocarcinoma cases [168] }\end{array}$ & 3rd Gen. TKIs & $\begin{array}{l}\text { MAPK overexpression, mutually exclusive with the } \\
\text { EGFR mutations }[167,169,170]\end{array}$ \\
\hline \multicolumn{4}{|c|}{ EMT } \\
\hline $\begin{array}{c}\text { AXL } \\
\text { (and ligand GAS6) }\end{array}$ & $7 / 35$ cases & 1st/2nd/3rd Gen. TKIs & EMT with vimentin overexpression [169] \\
\hline \multicolumn{4}{|c|}{ Histologic Transformation } \\
\hline Chronic EGFR Inhibition & $\begin{array}{l}\text { 5/37 1st Gen-resistance cases [170], } \\
2 \text { 3rd Gen-resistant case studies [171] }\end{array}$ & 1st/3rd Gen. TKIs & $\begin{array}{l}\text { Transformation to SCLC with EMT and potential } \\
\text { retinoblastoma signalling }[159,172,173]\end{array}$ \\
\hline
\end{tabular}


Table 3. Cont.

\begin{tabular}{|c|c|c|c|}
\hline Effector & Prevalence & Resistance To & Mechanism \\
\hline Chronic EGFR Inhibition & $\begin{array}{l}\text { 1st Gen-resistant case study }[172,173] \text {, } \\
\text { 5/71 3rd Gen-resistant cases [174] }\end{array}$ & 1st/3rd Gen. TKIs & Transformation from adenocarcinoma to SCC [172-174] \\
\hline \multicolumn{4}{|c|}{ Transcriptional Regulation } \\
\hline $\mathrm{NF}-\kappa \mathrm{B}$ & Statistical significance across 52 cases, Preclinical & 1st Gen. TKIs & $\begin{array}{l}\text { High NF- } \kappa B \text { activity predicted resistance via survival } \\
\text { signalling [175] }\end{array}$ \\
\hline Epigenetics & Preclinical & 1st Gen. TKIs & $\begin{array}{l}\text { miR-21 expression reducing PTEN and } \\
\text { PDCD4 activity [176] }\end{array}$ \\
\hline \multicolumn{4}{|c|}{ Oncogene Fusion } \\
\hline EIF4G2 & $1 / 32$ & 1st/2nd Gen. TKIs & Treatment-resistance associated fusion to GAB1 [177] \\
\hline ALK & $108 / 2835$ & 2nd/3rd Gen. TKI & $\begin{array}{c}\text { Treatment-resistance associated fusion to EML4, STRN, } \\
\text { CEBPZ predominantly in adenocarcinoma cases in } \\
\text { minimal smokers }[178,179]\end{array}$ \\
\hline NTRK1 & $4 / 3875$ cases & 2nd/3rd Gen. TKIs & $\begin{array}{l}\text { Treatment-resistance associated fusion to LRRC71, } \\
\text { PLEKHA6, RRL8, RP11 [178] }\end{array}$ \\
\hline RET & $6 / 3875$ cases & 3rd Gen. TKIs & $\begin{array}{c}\text { Treatment-resistance associated fusion to CCDC6, } \\
\text { MCPA4, CDC123, KIF5B }[178,181]\end{array}$ \\
\hline ROS1 & $3 / 3875$ cases & 3rd Gen. TKIs & Treatment-resistance associated fusion to DCBLD1 [178] \\
\hline FGFR3 & $5 / 32$ & 3rd Gen. TKIs & Treatment-resistance associated fusion to TACC3 [177] \\
\hline
\end{tabular}

* Please refer to Abbreviations for a list of the acronyms used in this table. 


\subsubsection{Acquired Resistance to First Generation TKIs}

Secondary EGFR mutations are the predominant mechanism of acquired resistance to first- and second-generation TKIs. Furthermore, the T790M mutation is solely attributed to $60 \%$ of acquired resistance cases with a presentation of indolent disease progression $[97,135,182-185]$. The mutation alters the ATP binding cleft preventing the binding of first- and second-generation TKIs [186]. Disease progression occurs with the positive selection of resistant clones indicated by an increasing proportion of circulating tumour cells expressing the resistant allele across serial measurements [187]. Circulating T790M cells did not indicate the onset of resistance but were a prognostic factor for earlier disease progression on first-generation TKIs. T790M not only arises during treatment but has also been identified in treatment-naive tumours and as a germline mutation inducing familial lung cancer predisposition [111,188-191]. Evidence of pre-existing mutations is consistent with a direct oncogenic role and in vitro demonstrations of enhanced EGFR phosphorylation and cancer-cell survival [192]. However, T790M resistance is complex and can be modified by concurrent mutations such as L858R, while gefitinib binding was unaffected by the dual T790M/L858R tumour yet resistance in this case emerged due to increased ATP affinity in the setting of the L858R variant [193,194]. Resistance has also been identified in other mutations, such as T854A and L747S/P, which sterically hinder TKI binding [131,133,140,141].

The T790M variant prompted the development of further TKI generations to address treatment resistance. While second-generation TKIs were unable to inhibit T790M-EGFR in vivo at clinical concentrations despite promising preclinical data, the third-generation agent osimertinib was successful at achieving inhibition $[150,195,196]$. Osimertinib was effective as a rescue medication after failing first-generation TKIs, with a median PFS of 10.1 months compared to 4.4 months on platinum-based chemotherapy, and as a first-line therapy with a median PFS of 18.9 months compared to 10.2 months for first-generation TKIs $[197,198]$. However, progression remains inevitable with patients demonstrating resistance to third-generation TKIs and disease progression.

The appearance of secondary mutations or the loss of the T790M clone that occurs with the emergence of acquired resistance can guide further targeted therapy. For resistance that emerges with de novo L474P or G724S mutations, recent reports demonstrate the clinical efficacy of second-generation afatinib rescue therapy. The L474P mutation in the N-terminal of the $\beta$ chain results in hydrophobic-centre conformational changes and constitutive kinase activation that was managed with afatinib with a much improved PFS of 24 months at the time of publication [140]. Similarly, the G724S mutation within the glycine-rich loop of the kinase domain induces a conformation change that prevents osimertinib-binding yet demonstrated in vitro sensitivity to afatinib $[149,199]$. This mutation was associated with T790M loss and an allelic bias towards 19del but not L858R tumours [149]. At the L817 residue, $\mathrm{L} 718 \mathrm{Q}$ is the predominant mutation that confers steric hindrance to osimertinibbinding as a first- and second-line medication [200,201]. In as many as 50\% of L718Q cases, a concurrent T790M mutation is lost at the time of disease progression, conferring sensitivity to first- and second-generation TKIs [200]. Hence, the status of the T790 residue may guide ongoing therapy at the time of disease progression.

\subsubsection{Acquired Resistance to Third-Generation TKIs}

The emergence of EGFR-mutant clones that display clinical resistance to all current TKI generations indicate the need for further drug development. Specifically, G796 residue mutations display clinical resistance to all TKIs via steric hindrance, even with the loss of a concurrent cis T790M mutation in the resistant clone at the time of disease progression $[145,146]$. Similarly, the L792F/H mutations present with multiallelic resistance patterns that complicate targeted therapy. Specifically, the mutant residue induces resistance via steric hindrance of a methoxy group on the methyl ring of osimertinib, which prevents binding [202]. While sole L792 mutants demonstrate in vitro sensitivity to first-generation TKIs, the mutant often presents with multiple mutations that lead to 
pan-TKI resistance. In particular, the L792 mutation reduces kinase hydrophobicity that results in a concurrent L858R residue displaying first-generation TKI resistance with or without coexisting T790M [145,150,202].

The C797S mutation is a variant with no current treatment options, yet novel inhibitors demonstrate a proof-of-concept for future mutation-specific targeted therapy. Resistance to third generation TKIs is mediated by impaired osimertinib binding to the C797 residue within the ATP-binding cleft [143]. When the C797 variants emerge in trans with T790M and 19del, a combination of first- and third-generation TKIs achieved a PFS of 7.4 months until the emergence of a cis clone with pan-TKI resistance [143,203,204]. However, a novel preclinical allosteric inhibitor was found to inhibit EGFR kinase activity by targeting the inactive EGF monomer at an allosteric site outside the kinase binding cleft in the presence of the cetuximab-induced inhibition of dimerisation [144,205]. Achieving kinase inhibition outside the ATP-binding cleft that is targeted by current TKI therapies demonstrates a proof-of-concept for future therapies to manage and reduce the emergence of resistance.

\subsubsection{Acquired Resistance via Downstream Activation}

Resistance to targeted kinase therapy emerges through signalling aberrations downstream of the initiating EGFR-mutation. These signalling aberrations emerge in posttreatment tumour biopsies and are attributed to resistance to all TKI generations via activation of mitogen-activated protein kinase kinase (MEK)/extracellular signal regulated kinase (ERK), and Akt/mTOR pathways. Within the Akt/mTOR pathway, mutations have been demonstrated in patient-derived tumours within PIK3CA, PTEN, and AKT1 that lead to increased Akt phosphorylation, mTOR-mediated survival signalling, and early disease progression [162-165]. Treatment with the mTOR inhibitor everolimus achieved a disappointing PFS of 2.1 months, indicating the requirement for targeted therapies in emergent resistance [165]. However, strategies are complicated by concurrent EGFR mutations, downstream mutations, and cross-activation from PIK3CA to MEK pathways $[165,206]$. Within the MEK/ERK proliferation pathway, BRAF and KRAS mutations contribute to resistance. BRAF mutations comprised $50 \%$ of $\mathrm{V} 600 \mathrm{E}$, whereas NRAF mutations were associated with an upstream KRAS mutation [207]. In vitro, resistance was overcome by MEK and BRAF inhibition and was dependent on ERK signalling with no AKT phosphorylation $[166,167]$. KRAS mutations were previously thought to be mutually exclusive with EGFR mutations and are a well-defined resistance mechanism to EGFR-mAbs in colorectal cancer $[208,209]$. However, post-TKI tumour biopsies have confirmed KRAS mutations in new osimertinib resistance in conjunction with new EGFR mutations, with resistance ameliorated via Ras-ERK inhibition in vitro [210,211]. Hence, mutations downstream of EGFR can induce or complicate the emergence of TKI resistance.

\subsubsection{Acquired Resistance via Alternative Pathways}

Enhancement of alternative pathways is demonstrated to induce resistance to targeted kinase therapy by bypassing EGFR to activate MEK/ERK and AKT/mTOR signalling. MET signalling is a well-described pathway in which amplification or protein overactivation phosphorylates ErbB3 and bypasses EGFR to activate Akt [212]. MET amplification is associated with poorer patient outcomes and acquired resistance, including a median PFS of 3.5 months compared to 9.9 months without MET amplification. The MET copy number was a biomarker that predicted poor outcomes and poor response to therapy $[213,214]$. However, combination treatment with the MET/C-ros oncogene 1(ROS1)/anaplastic lymphoma kinase (ALK) inhibitor capmatinib and gefitinib in acquired resistance cases achieved a modest improvement of PFS to 5.5 months [215]. Resistance is proposed to emerge either from the selection of clones present in treatment-naïve tumours or through MET activation following the increased secretion of the endogenous ligand hepatocyte growth factor (HGF) [216,217]. Treatment options are limited for tumours that possess bypass signalling. For example, HER2 mutant or amplified tumours with bypass ERK activation achieved a mere $18 \%$ response rate and 3.9 months median PFS 
with trastuzumab/afatinib combination therapy $[159,218]$. Furthermore, the screening of patients with progressive disease has identified poorly described resistance-associated mutations involving multiple mechanisms. Resistance mediated via fibroblast growth factor receptor 1 (FGFR1) and MAPK mutations occurred through increased canonical ERK and ALK signalling $[153,219,220]$. However, mutations affecting the Crk-like protein (CRKL) and insulin-like growth factor 1 receptor (IGF1R) acted at the receptor complex to enhance downstream signalling via increased adaptor protein amplification or affinity, respectively $[151,221,222]$. Therefore, targeted therapy for bypass signalling in the setting of acquired TKI resistance is a developing field with ongoing current clinical trials.

\subsubsection{Acquired Resistance via Other Mechanisms}

The heterogeneity of non-small cell lung cancer is evident in the diverse genetic and cellular mechanisms of acquired resistance. Histologic transformation represents the progression of a primary or secondary tumour to either a small cell or squamous cell carcinoma [223]. The transformed tumours are identifiable by possessing the same sensitising or resistance markers as the initial tumour yet adopting a clinical presentation and treatment sensitivity specific to the new histological classification [170]. Transformation occurs most commonly within the selection pressure of initial TKI treatment that either results in the expansion of a specific clone or the differentiation of cancer stem cells within the heterogenous tumour $[170,174]$. Epithelial to mesenchymal transition (EMT) can accompany transformation or occur in isolation from it and is associated with an upregulation of AXL and vimentin and a downregulation of E-cadherin, yet the significance has not yet been incorporated into clinical approaches [169]. Genetic mechanisms include the rare event of oncogene fusion, in which oncogenes activate downstream signalling and bypass EGFR inhibition [180]. Fusions are observed at a greater frequency in acquired resistance than in first-generation TKIs (16\% vs. 3\%) [177]. The study of ALK and RAF suggest that the specific binding partner of oncogene fusions may influence the emergence and drug-specificity of resistance amidst an increasing number of observed fusion partners [224,225]. Fusion-dependent tumours retained sensitising mutations and lost T790M resistance mutation in 75\% of cases [177]. Acquired resistance is further attributed to novel mechanisms including epigenetic silencing via microRNA and nuclear factor kappa-light-chain-enhancer of activated B cells (NF- $\mathrm{kB}$ ) transcriptional regulation in vitro, however, the significance has yet to be established in the clinic $[175,176]$.

\subsection{Monoclonal Antibody $(m A b)$ Therapy}

Therapeutic mAbs are used in the treatment of cancers by binding to the specific target cell antigens responsible for growth and differentiation. Anti-EGFR mAbs bind to the surface of EGFR via an antigen-binding fragment (Fab) and competitively block the binding of EGF [226]. Antibody-receptor complexes are then internalised and degraded, leading to EGFR down-regulation on the surface of tumour cells. Therapeutic mAbs also act via immulogical mechanisms such as antibody-dependent cellular cytotoxicity (ADCC), which involve antibodies coating the target cell, effector cells recognising the antibody, and consequent effector-cell-induced apoptosis [226].

Unfortunately, despite their success in other cancer types, such as colorectal carcinoma and head and neck SCC (Table 2), mAb therapy has had uninspiring results in NSCLC and is not currently approved for its treatment. Two phase III studies, FLEX and BMS099, have investigated the combination of cetuximab with chemotherapy in advanced NSCLC and demonstrated a minimal improvement and no improvement in overall survival, respectively [93,227]. Preclinical evidence demonstrates that mAbs can achieve disease control in dimerisation-dependent L858R tumours but not in dimerisation-independent 19del tumours [228]. This dimerisation-dependent mechanism underlies the clinical use of mAbs in EGFR-mutants that possess changes in the intermolecular dimerisation affinity. Specifically, structural modelling predicts that exon 20 insertions bias the electrostatic affinity towards the formation of active EGFR dimers through conformational changes that prevent 
C-helix reorientation to the inactive state [229]. The addition of cetuximab in combination with osimertinib or afatinib for the treatment of exon 20 insertion tumours have achieved a PFS of 5.4 months and 6.4 months, respectively [230]. Furthermore, osimertinib with necitumumab (another anti-EGFR $\mathrm{mAb}$ ) combination therapy achieved a median PFS of 6.4 months in a tumour containing the EGFR C797S variant, which is predicted to have increased intermolecular interaction due to hydrogen bonding between the mutation and EGFR R841 [231,232]. Therefore, a greater structural understanding of receptor activation in EGFR-mutant tumours may yield biomarkers for $\mathrm{mAb}$ combination therapy in cases of acquired resistance.

\section{Conclusions}

EGFR-targeting therapies have dramatically altered the treatment landscape of a number of cancers. The underlying mechanism of EGFR overexpression has a significant impact on treatment response and the development of resistance. In cancers such as head and neck, where the majority of tumours overexpress EGFR, antibodies inducing effects such as ADCP and ADCC are clinically relevant. In NSCLC, a therapeutic approach is differentiated with regard to mutant-EGFR and the development of resistance to anti-EGFR therapy through various mechanisms including gene line polymorphisms, secondary EGFR mutations, enhancement of alternate signalling pathways, and downstream signalling pathway protein mutations. Further research into these mechanisms of resistance and the nature of EGFR expression will allow the development of superior therapeutic techniques to help improve the outcomes of patients with NSCLC. The approach to EGFR targeting in each cancer thus depends on the type of EGFR dysregulation specific to each tumour type.

\section{Patents}

Granted patents: PAT-02100-JP-01; 2015-538212; PAT-02100-GB-01; 13848409.2; PAT02100-DE-01; 60 2013059561.5; PAT-02100-AU-02; 2013334493; PAT-02100-US-01 14/438440; PAT-02100-JP-01 2015-538212.

Funding: This work was funded by an NHMRC Ideas grant to FS APP2001396.

Institutional Review Board Statement: Not applicable.

Informed Consent Statement: Not applicable.

Acknowledgments: The authors acknowledge the Translational Research Institute and University of Queensland for providing an excellent research environment. This work was supported by the Australian Government Research Training Program Scholarship.

Conflicts of Interest: The authors declare no conflict of interest.

\section{Abbreviations}

$\begin{array}{ll}\text { Acronym } & \text { Definition } \\ \text { AGAP3 } & \text { ArfGAP with GTPase Domain, Ankyrin Repeat and PH Domain } 3 \\ \text { AGK } & \text { Acylglycerol kinase } \\ \text { Akt } & \text { Protein kinase B } \\ \text { AKT1 } & \text { AKT Serine/Threonine Kinase 1 } \\ \text { ALK } & \text { Anaplastic lymphoma kinase } \\ \text { ARMC10 } & \text { Armadillo Repeat Containing 10 } \\ \text { ATP } & \text { Adenosine triphosphate } \\ \text { BIM } & \text { B cell lymphoma-2-like } \\ \text { BRAF } & \text { B-Raf Proto-Oncogene } \\ \text { CCDC6 } & \text { Coiled-Coil Domain Containing 6 } \\ \text { CDC123 } & \text { Cell Division Cycle 123 }\end{array}$




\begin{tabular}{|c|c|}
\hline CEBPZ & CCAAT Enhancer Binding Protein Zeta \\
\hline CRKL & CRK like proto-oncogene \\
\hline DCBLD1 & Discoidin, CUB and LCCL Domain Containing 1 \\
\hline DOCK4 & Dedicator of cytokinesis 4 \\
\hline EGFR & Epidermal growth factor receptor \\
\hline EIF4G2 & Eukaryotic translation initiation factor 4 gamma 2 \\
\hline EMT & Epithelial to mesenchymal transition \\
\hline EPS15 & Epidermal growth factor receptor substrate 15 \\
\hline ERK & Extracellular-signal-regulated kinase \\
\hline FGFR & Fibroblast growth factor receptor \\
\hline GAB1 & Grb2 associated binding protein 1 \\
\hline GAS6 & Growth arrest specific 6 \\
\hline HER & Human epidermal growth factor receptor 2 \\
\hline IGF1R & Insulin like growth factor 1 receptor \\
\hline KIF5B & Kinesin Family Member 5B \\
\hline KRAS & Kirsten rate sarcoma viral oncogene \\
\hline LRRC71 & Leucine rich repeat containing 71 \\
\hline MAPK & Mitogen-activated protein kinase \\
\hline MEK & Mitogen-activated protein kinase kinase \\
\hline $\operatorname{miR}-21$ & mircoRNA 21 \\
\hline mTOR & Mechanistic target of rapamycin \\
\hline $\mathrm{NF}-\kappa \mathrm{B}$ & Nuclear factor kappa-light-chain-enhancer of activated B cells \\
\hline NTRK1 & Neurotrophic Receptor Tyrosine Kinase 1 \\
\hline PDCD4 & Programmed Cell Death 4 \\
\hline PFS & Progression free survival \\
\hline PI3K & Phosphoinositide 3-kinase \\
\hline PIЗКСА & PI3K catalytic subunit alpha \\
\hline PLEKHA6 & Pleckstrin homology domain containing A6 \\
\hline PTEN & Phosphatase and tensin homolog \\
\hline OS & Overall survival \\
\hline RET & Rearranged during transfection \\
\hline ROS1 & C-ros oncogene 1 \\
\hline SALL2 & Spalt like transcription factor 2 \\
\hline SCC & Squamous cell carcinoma \\
\hline SCLC & Small cell lung cancer \\
\hline STRN & Striatin \\
\hline TACC3 & Transforming acidic coiled-coil containing protein 3 \\
\hline TKI & Tyrosine kinase inhibitor \\
\hline TRIM24 & Tripartite Motif Containing 24 \\
\hline
\end{tabular}

\section{References}

1. Fitzmaurice, C.; Dicker, D.; Pain, A.; Hamavid, H.; Moradi-Lakeh, M.; MacIntyre, M.F.; Allen, C.; Hansen, G.; Woodbrook, R.; Wolfe, C. The global burden of cancer 2013. JAMA Oncol. 2015, 1, 505-527. [CrossRef] [PubMed]

2. Sher, T.; Dy, G.K.; Adjei, A.A. Small cell lung cancer. Mayo Clin. Proc. 2008, 83, 355-367. [CrossRef] [PubMed]

3. Travis, W.D.; Brambilla, E.; Burke, A.P.; Marx, A.; Nicholson, A.G. Introduction to the 2015 World Health Organization classification of tumors of the lung, pleura, thymus, and heart. J. Thorac. Oncol. 2015, 10, 1240-1242. [CrossRef] [PubMed]

4. Travis, W.D.; Brambilla, E.; Nicholson, A.G.; Yatabe, Y.; Austin, J.H.; Beasley, M.B.; Chirieac, L.R.; Dacic, S.; Duhig, E.; Flieder, D.B. The 2015 World Health Organization classification of lung tumors: Impact of genetic, clinical and radiologic advances since the 2004 classification. J. Thorac. Oncol. 2015, 10, 1243-1260. [CrossRef]

5. Zhou, F.; Zhou, C. Lung cancer in never smokers-the East Asian experience. Transl. Lung Cancer Res. 2018, 7, 450-463. [CrossRef]

6. Garinet, S.; Laurent-Puig, P.; Blons, H.; Oudart, J.-B. Current and Future Molecular Testing in NSCLC, What Can We Expect from New Sequencing Technologies? J. Clin. Med. 2018, 7, 144. [CrossRef]

7. Barlesi, F.; Mazieres, J.; Merlio, J.-P.; Debieuvre, D.; Mosser, J.; Lena, H.; Ouafik, L.H.; Besse, B.; Rouquette, I.; Westeel, V. Routine molecular profiling of patients with advanced non-small-cell lung cancer: Results of a 1-year nationwide programme of the French Cooperative Thoracic Intergroup (IFCT). Lancet 2016, 387, 1415-1426. [CrossRef] 
8. Kris, M.G.; Johnson, B.E.; Berry, L.D.; Kwiatkowski, D.J.; Iafrate, A.J.; Wistuba, I.I.; Varella-Garcia, M.; Franklin, W.A.; Aronson, S.L.; Su, P.-F. Using multiplexed assays of oncogenic drivers in lung cancers to select targeted drugs. JAMA 2014, 311, 1998-2006. [CrossRef]

9. da Cunha Santos, G.; Shepherd, F.A.; Tsao, M.S. EGFR mutations and lung cancer. Annu. Rev. Pathol. 2011, 6, 49-69. [CrossRef]

10. Tseng, C.H.; Chiang, C.J.; Tseng, J.S.; Yang, T.Y.; Hsu, K.H.; Chen, K.C.; Wang, C.L.; Chen, C.Y.; Yen, S.H.; Tsai, C.M.; et al. EGFR mutation, smoking, and gender in advanced lung adenocarcinoma. Oncotarget 2017, 8, 98384-98393. [CrossRef]

11. Thomas, R.; Weihua, Z. Rethink of EGFR in Cancer with Its Kinase Independent Function on Board. Front. Oncol. 2019, 9, 800. [CrossRef]

12. Pelloski, C.E.; Ballman, K.V.; Furth, A.F.; Zhang, L.; Lin, E.; Sulman, E.P.; Bhat, K.; McDonald, J.M.; Yung, W.K.; Colman, H.; et al. Epidermal growth factor receptor variant III status defines clinically distinct subtypes of glioblastoma. J. Clin. Oncol. 2007, 25, 2288-2294. [CrossRef]

13. Sugawa, N.; Ekstrand, A.J.; James, C.D.; Collins, V.P. Identical splicing of aberrant epidermal growth factor receptor transcripts from amplified rearranged genes in human glioblastomas. Proc. Natl. Acad. Sci. USA 1990, 87, 8602-8606. [CrossRef]

14. Del Vecchio, C.; Giacomini, C.; Vogel, H.; Jensen, K.; Florio, T.; Merlo, A.; Pollack, J.; Wong, A. EGFRvIII gene rearrangement is an early event in glioblastoma tumorigenesis and expression defines a hierarchy modulated by epigenetic mechanisms. Oncogene 2013, 32, 2670-2681. [CrossRef]

15. De Luca, A.; Normanno, N. Predictive biomarkers to tyrosine kinase inhibitors for the epidermal growth factor receptor in non-small-cell lung cancer. Curr. Drug Targets 2010, 11, 851-864. [CrossRef]

16. Li, A.R.; Chitale, D.; Riely, G.J.; Pao, W.; Miller, V.A.; Zakowski, M.F.; Rusch, V.; Kris, M.G.; Ladanyi, M. EGFR mutations in lung adenocarcinomas: Clinical testing experience and relationship to EGFR gene copy number and immunohistochemical expression. J. Mol. Diagn. 2008, 10, 242-248. [CrossRef]

17. Jung, M.J.; Woo, C.G.; Lee, S.; Chin, S.; Kim, H.K.; Kwak, J.J.; Koh, E.S.; Lee, B.; Jang, K.-T.; Moon, A. Gene copy number variation and protein overexpression of EGFR and HER2 in distal extrahepatic cholangiocarcinoma. Pathology 2017, 49, 582-588. [CrossRef]

18. Birkman, E.-M.; Ålgars, A.; Lintunen, M.; Ristamäki, R.; Sundström, J.; Carpén, O. EGFR gene amplification is relatively common and associates with outcome in intestinal adenocarcinoma of the stomach, gastro-oesophageal junction and distal oesophagus. BMC Cancer 2016, 16, 1-14. [CrossRef]

19. Yang, X.; Wang, W.; Wang, C.; Wang, L.; Yang, M.; Qi, M.; Su, H.; Sun, X.; Liu, Z.; Zhang, J. Characterization of EGFR family gene aberrations in cholangiocarcinoma. Oncol. Rep. 2014, 32, 700-708. [CrossRef]

20. Rossi, E.; Villanacci, V.; Danesino, C.; Donato, F.; Nascimbeni, R.; Bassotti, G. Epidermal growth factor receptor overexpression/amplification in adenocarcinomas arising in the gastrointestinal tract. Rev. Esp. Enferm. Dig. 2011, 103, 632-639. [CrossRef]

21. Huang, S.-F.; Cheng, S.-D.; Chien, H.-T.; Liao, C.-T.; Chen, I.-H.; Wang, H.-M.; Chuang, W.-Y.; Wang, C.-Y.; Hsieh, L.-L. Relationship between epidermal growth factor receptor gene copy number and protein expression in oral cavity squamous cell carcinoma. Oral Oncol. 2012, 48, 67-72. [CrossRef] [PubMed]

22. Itakura, Y.; Sasano, H.; Shiga, C.; Furukawa, Y.; Shiga, K.; Mori, S.; Nagura, H. Epidermal growth factor receptor overexpression in esophageal carcinoma. An immunohistochemical study correlated with clinicopathologic findings and DNA amplification. Cancer 1994, 74, 795-804. [CrossRef]

23. Lemmon, M.A.; Schlessinger, J. Cell signaling by receptor tyrosine kinases. Cell 2010, 141, 1117-1134. [CrossRef] [PubMed]

24. Oda, K.; Matsuoka, Y.; Funahashi, A.; Kitano, H. A comprehensive pathway map of epidermal growth factor receptor signaling. Mol. Syst. Biol. 2005, 1, 2005.0010. [CrossRef] [PubMed]

25. Yarden, Y.; Sliwkowski, M.X. Untangling the ErbB signalling network. Nat. Rev. Mol. Cell Biol. 2001, 2, 127-137. [CrossRef]

26. Wang, Z. ErbB Receptors and Cancer. Methods Mol. Biol. 2017, 1652, 3-35. [CrossRef]

27. Normanno, N.; De Luca, A.; Bianco, C.; Strizzi, L.; Mancino, M.; Maiello, M.R.; Carotenuto, A.; De Feo, G.; Caponigro, F.; Salomon, D.S. Epidermal growth factor receptor (EGFR) signaling in cancer. Gene 2006, 366, 2-16. [CrossRef]

28. Jorissen, R.N.; Walker, F.; Pouliot, N.; Garrett, T.P.; Ward, C.W.; Burgess, A.W. Epidermal growth factor receptor: Mechanisms of activation and signalling. Exp. Cell Res. 2003, 284, 31-53. [CrossRef]

29. Wee, P.; Wang, Z. Epidermal Growth Factor Receptor Cell Proliferation Signaling Pathways. Cancers (Basel) 2017, 9. [CrossRef]

30. Quesnelle, K.M.; Boehm, A.L.; Grandis, J.R. STAT-mediated EGFR signaling in cancer. J. Cell. Biochem. 2007, 102, 311-319. [CrossRef]

31. Kumar, A.; Petri, E.T.; Halmos, B.; Boggon, T.J. Structure and clinical relevance of the epidermal growth factor receptor in human cancer. J. Clin. Oncol. 2008, 26, 1742-1751. [CrossRef]

32. Chan, B.A.; Hughes, B.G. Targeted therapy for non-small cell lung cancer: Current standards and the promise of the future. Transl. Lung Cancer Res. 2015, 4, 36-54. [CrossRef]

33. Pao, W.; Miller, V.; Zakowski, M.; Doherty, J.; Politi, K.; Sarkaria, I.; Singh, B.; Heelan, R.; Rusch, V.; Fulton, L. EGF receptor gene mutations are common in lung cancers from "never smokers" and are associated with sensitivity of tumors to gefitinib and erlotinib. Proc. Natl. Acad. Sci. USA 2004, 101, 13306-13311. [CrossRef]

34. Ohsaki, Y.; Tanno, S.; Fujita, Y.; Toyoshima, E.; Fujiuchi, S.; Nishigaki, Y.; Ishida, S.; Nagase, A.; Miyokawa, N.; Hirata, S. Epidermal growth factor receptor expression correlates with poor prognosis in non-small cell lung cancer patients with p53 overexpression. Oncol. Rep. 2000, 7, 603-610. [CrossRef] 
35. Pastorino, U.; Andreola, S.; Tagliabue, E.; Pezzella, F.; Incarbone, M.; Sozzi, G.; Buyse, M.; Menard, S.; Pierotti, M.; Rilke, F. Immunocytochemical markers in stage I lung cancer: Relevance to prognosis. J. Clin. Oncol. 1997, 15, 2858-2865. [CrossRef]

36. Pfeiffer, P.; Clausen, P.; Andersen, K.; Rose, C. Lack of prognostic significance of epidermal growth factor receptor and the oncoprotein p185 HER-2 in patients with systemically untreated non-small-cell lung cancer: An immunohistochemical study on cryosections. Br. J. Cancer 1996, 74, 86-91. [CrossRef]

37. Cox, G.; Jones, J.L.; O’Byrne, K.J. Matrix metalloproteinase 9 and the epidermal growth factor signal pathway in operable non-small cell lung cancer. Clin. Cancer Res. 2000, 6, 2349-2355.

38. Hirsch, F.R.; Scagliotti, G.V.; Langer, C.J.; Varella-Garcia, M.; Franklin, W.A. Epidermal growth factor family of receptors in preneoplasia and lung cancer: Perspectives for targeted therapies. Lung Cancer 2003, 41, 29-42. [CrossRef]

39. Rusch, V.; Klimstra, D.; Venkatraman, E.; Pisters, P.; Langenfeld, J.; Dmitrovsky, E. Overexpression of the epidermal growth factor receptor and its ligand transforming growth factor alpha is frequent in resectable non-small cell lung cancer but does not predict tumor progression. Clin. Cancer Res. 1997, 3, 515-522.

40. Selvaggi, G.; Novello, S.; Torri, V.; Leonardo, E.; De Giuli, P.; Borasio, P.; Mossetti, C.; Ardissone, F.; Lausi, P.; Scagliotti, G.V. Epidermal growth factor receptor overexpression correlates with a poor prognosis in completely resected non-small-cell lung cancer. Ann. Oncol. 2004, 15, 28-32. [CrossRef]

41. Fontanini, G.; De Laurentiis, M.; Vignati, S.; Chinè, S.; Lucchi, M.; Silvestri, V.; Mussi, A.; De Placido, S.; Tortora, G.; Bianco, A.R. Evaluation of epidermal growth factor-related growth factors and receptors and of neoangiogenesis in completely resected stage I-IIIA non-small-cell lung cancer: Amphiregulin and microvessel count are independent prognostic indicators of survival. Clin. Cancer Res. 1998, 4, 241-249. [PubMed]

42. Volm, M.; Rittgen, W.; Drings, P. Prognostic value of ERBB-1, VEGF, cyclin A, FOS, JUN and MYC in patients with squamous cell lung carcinomas. Br. J. Cancer 1998, 77, 663-669. [CrossRef] [PubMed]

43. Greatens, T.M.; Niehans, G.A.; Rubins, J.B.; Jessurun, J.; Kratzke, R.A.; Maddaus, M.A.; Niewoehner, D.E. Do molecular markers predict survival in non-small-cell lung cancer? Am. J. Respir. Crit. Care Med. 1998, 157, 1093-1097. [CrossRef]

44. Nakamura, H.; Kawasaki, N.; Taguchi, M.; Kabasawa, K. Survival impact of epidermal growth factor receptor overexpression in patients with non-small cell lung cancer: A meta-analysis. Thorax 2006, 61, 140-145. [CrossRef] [PubMed]

45. AACR Project GENIE: Powering Precision Medicine through an International Consortium. Cancer Discov. $2017,7,818-831$. [CrossRef] [PubMed]

46. Spindler, K.L.; Lindebjerg, J.; Nielsen, J.N.; Olsen, D.A.; Bisgård, C.; Brandslund, I.; Jakobsen, A. Epidermal growth factor receptor analyses in colorectal cancer: A comparison of methods. Int. J. Oncol. 2006, 29, 1159-1165. [CrossRef] [PubMed]

47. Scartozzi, M.; Bearzi, I.; Berardi, R.; Mandolesi, A.; Fabris, G.; Cascinu, S. Epidermal growth factor receptor (EGFR) status in primary colorectal tumors does not correlate with EGFR expression in related metastatic sites: Implications for treatment with EGFR-targeted monoclonal antibodies. J. Clin. Oncol. 2004, 22, 4772-4778. [CrossRef]

48. Saltz, L.B.; Meropol, N.J.; Loehrer, P.J., Sr.; Needle, M.N.; Kopit, J.; Mayer, R.J. Phase II trial of cetuximab in patients with refractory colorectal cancer that expresses the epidermal growth factor receptor. J. Clin. Oncol. 2004, 22, 1201-1208. [CrossRef]

49. Goldstein, N.S.; Armin, M. Epidermal growth factor receptor immunohistochemical reactivity in patients with American Joint Committee on Cancer Stage IV colon adenocarcinoma. Cancer 2001, 92, 1331-1346. [CrossRef]

50. Hashmi, A.A.; Hussain, Z.F.; Aijaz, S.; Irfan, M.; Khan, E.Y.; Naz, S.; Faridi, N.; Khan, A.; Edhi, M.M. Immunohistochemical expression of epidermal growth factor receptor (EGFR) in South Asian head and neck squamous cell carcinoma: Association with various risk factors and clinico-pathologic and prognostic parameters. World J. Surg. Oncol. 2018, 16, 118. [CrossRef]

51. Grandis, J.R.; Tweardy, D.J. Elevated levels of transforming growth factor alpha and epidermal growth factor receptor messenger RNA are early markers of carcinogenesis in head and neck cancer. Cancer Res. 1993, 53, 3579-3584.

52. Boeck, S.; Jung, A.; Laubender, R.P.; Neumann, J.; Egg, R.; Goritschan, C.; Vehling-Kaiser, U.; Winkelmann, C.; Fischer von Weikersthal, L.; Clemens, M.R.; et al. EGFR pathway biomarkers in erlotinib-treated patients with advanced pancreatic cancer: Translational results from the randomised, crossover phase 3 trial AIO-PK0104. Br. J. Cancer 2013, 108, 469-476. [CrossRef]

53. Dancer, J.; Takei, H.; Ro, J.Y.; Lowery-Nordberg, M. Coexpression of EGFR and HER-2 in pancreatic ductal adenocarcinoma: A comparative study using immunohistochemistry correlated with gene amplification by fluorescencent in situ hybridization. Oncol. Rep. 2007, 18, 151-155. [CrossRef]

54. Bloomston, M.; Bhardwaj, A.; Ellison, E.C.; Frankel, W.L. Epidermal growth factor receptor expression in pancreatic carcinoma using tissue microarray technique. Dig. Surg. 2006, 23, 74-79. [CrossRef]

55. Gonzalez-Conchas, G.A.; Rodriguez-Romo, L.; Hernandez-Barajas, D.; Gonzalez-Guerrero, J.F.; Rodriguez-Fernandez, I.A.; Verdines-Perez, A.; Templeton, A.J.; Ocana, A.; Seruga, B.; Tannock, I.F. Epidermal growth factor receptor overexpression and outcomes in early breast cancer: A systematic review and a meta-analysis. Cancer Treat. Rev. 2018, 62, 1-8. [CrossRef]

56. Di Lorenzo, G.; Tortora, G.; D'Armiento, F.P.; De Rosa, G.; Staibano, S.; Autorino, R.; D'Armiento, M.; De Laurentiis, M.; De Placido, S.; Catalano, G. Expression of epidermal growth factor receptor correlates with disease relapse and progression to androgen-independence in human prostate cancer. Clin. Cancer Res. 2002, 8, 3438-3444.

57. de Muga, S.; Hernández, S.; Agell, L.; Salido, M.; Juanpere, N.; Lorenzo, M.; Lorente, J.A.; Serrano, S.; Lloreta, J. Molecular alterations of EGFR and PTEN in prostate cancer: Association with high-grade and advanced-stage carcinomas. Mod. Pathol. 2010, 23, 703-712. [CrossRef] 
58. Lin, G.; Sun, X.-J.; Han, Q.-B.; Wang, Z.; Xu, Y.-P.; Gu, J.-L.; Wu, W.; Zhang, G.U.; Hu, J.-L.; Sun, W.-Y.; et al. Epidermal growth factor receptor protein overexpression and gene amplification are associated with aggressive biological behaviors of esophageal squamous cell carcinoma. Oncol. Lett. 2015, 10, 901-906. [CrossRef]

59. Abedi-Ardekani, B.; Dar, N.A.; Mir, M.M.; Zargar, S.A.; Lone, M.M.; Martel-Planche, G.; Villar, S.; Mounawar, M.; Saidi, F.; Malekzadeh, R.; et al. Epidermal growth factor receptor (EGFR) mutations and expression in squamous cell carcinoma of the esophagus in central Asia. BMC Cancer 2012, 12, 602. [CrossRef]

60. Kim, M.A.; Lee, H.S.; Lee, H.E.; Jeon, Y.K.; Yang, H.K.; Kim, W.H. EGFR in gastric carcinomas: Prognostic significance of protein overexpression and high gene copy number. Histopathology 2008, 52, 738-746. [CrossRef]

61. Galizia, G.; Lieto, E.; Orditura, M.; Castellano, P.; Mura, A.L.; Imperatore, V.; Pinto, M.; Zamboli, A.; De Vita, F.; Ferraraccio, F. Epidermal growth factor receptor (EGFR) expression is associated with a worse prognosis in gastric cancer patients undergoing curative surgery. World J. Surg. 2007, 31, 1458-1468. [CrossRef] [PubMed]

62. Kira, S.; Nakanishi, T.; Suemori, S.; Kitamoto, M.; Watanabe, Y.; Kajiyama, G. Expression of transforming growth factor alpha and epidermal growth factor receptor in human hepatocellular carcinoma. Liver 1997, 17, 177-182. [CrossRef] [PubMed]

63. Ito, Y.; Takeda, T.; Sakon, M.; Tsujimoto, M.; Higashiyama, S.; Noda, K.; Miyoshi, E.; Monden, M.; Matsuura, N. Expression and clinical significance of erb-B receptor family in hepatocellular carcinoma. Br. J. Cancer 2001, 84, 1377-1383. [CrossRef] [PubMed]

64. Watanabe, K.; Tachibana, O.; Sata, K.; Yonekawa, Y.; Kleihues, P.; Ohgaki, H. Overexpression of the EGF receptor and p53 mutations are mutually exclusive in the evolution of primary and secondary glioblastomas. Brain Pathol. 1996, 6, 217-223, discussion 223-214. [CrossRef]

65. Stadlmann, S.; Gueth, U.; Reiser, U.; Diener, P.A.; Zeimet, A.G.; Wight, E.; Mirlacher, M.; Sauter, G.; Mihatsch, M.J.; Singer, G. Epithelial growth factor receptor status in primary and recurrent ovarian cancer. Mod. Pathol. 2006, 19, 607-610. [CrossRef]

66. Hashmi, A.A.; Hussain, Z.F.; Irfan, M.; Khan, E.Y.; Faridi, N.; Naqvi, H.; Khan, A.; Edhi, M.M. Prognostic significance of epidermal growth factor receptor (EGFR) over expression in urothelial carcinoma of urinary bladder. BMC Urol. 2018, 18, 59. [CrossRef]

67. Carlsson, J.; Wester, K.; De La Torre, M.; Malmström, P.-U.; Gårdmark, T. EGFR-expression in primary urinary bladder cancer and corresponding metastases and the relation to HER2-expression. On the possibility to target these receptors with radionuclides. Radiol. Oncol. 2015, 49, 50-58. [CrossRef]

68. Uhlman, D.L.; Nguyen, P.; Manivel, J.C.; Zhang, G.; Hagen, K.; Fraley, E.; Aeppli, D.; Niehans, G.A. Epidermal growth factor receptor and transforming growth factor alpha expression in papillary and nonpapillary renal cell carcinoma: Correlation with metastatic behavior and prognosis. Clin. Cancer Res. 1995, 1, 913-920.

69. Moch, H.; Sauter, G.; Buchholz, N.; Gasser, T.C.; Bubendorf, L.; Waldman, F.M.; Mihatsch, M.J. Epidermal growth factor receptor expression is associated with rapid tumor cell proliferation in renal cell carcinoma. Hum. Pathol. 1997, 28, 1255-1259. [CrossRef]

70. Cossu-Rocca, P.; Muroni, M.R.; Sanges, F.; Sotgiu, G.; Asunis, A.; Tanca, L.; Onnis, D.; Pira, G.; Manca, A.; Dore, S.; et al. EGFR kinase-dependent and kinase-independent roles in clear cell renal cell carcinoma. Am. J. Cancer Res. 2016, 6, 71-83.

71. Rosell, R.; Moran, T.; Queralt, C.; Porta, R.; Cardenal, F.; Camps, C.; Majem, M.; Lopez-Vivanco, G.; Isla, D.; Provencio, M. Screening for epidermal growth factor receptor mutations in lung cancer. N. Engl. J. Med. 2009, 361, 958-967. [CrossRef]

72. Cancer Genome Atlas Network. Comprehensive molecular portraits of human breast tumours. Nature 2012, 490, 61-70. [CrossRef]

73. Shi, Y.; Au, J.S.-K.; Thongprasert, S.; Srinivasan, S.; Tsai, C.-M.; Khoa, M.T.; Heeroma, K.; Itoh, Y.; Cornelio, G.; Yang, P.-C. A prospective, molecular epidemiology study of EGFR mutations in Asian patients with advanced non-small-cell lung cancer of adenocarcinoma histology (PIONEER). J. Thorac. Oncol. 2014, 9, 154-162. [CrossRef]

74. Xu, Y.-H.; Richert, N.; Ito, S.; Merlino, G.T.; Pastan, I. Characterization of epidermal growth factor receptor gene expression in malignant and normal human cell lines. Proc. Natl. Acad. Sci. USA 1984, 81, 7308-7312. [CrossRef]

75. King, C.R.; Kraus, M.H.; Williams, L.T.; Merlino, G.T.; Pastan, I.H.; Aaronson, S.A. Human tumor cell lines with EGF receptor gene amplification in the absence of aberrant sized mRNAs. Nucleic Acids Res. 1985, 13, 8477-8486. [CrossRef]

76. Merlino, G.; Ishii, S.; Whang-Peng, J.; Knutsen, T.; Xu, Y.; Clark, A.; Stratton, R.; Wilson, R.; Ma, D.P.; Roe, B. Structure and localization of genes encoding aberrant and normal epidermal growth factor receptor RNAs from A431 human carcinoma cells. Mol. Cell. Biol. 1985, 5, 1722-1734. [CrossRef]

77. Merlino, G.; Xu, Y.; Richert, N.; Clark, A.; Ishii, S.; Banks-Schlegel, S.; Pastan, I. Elevated epidermal growth factor receptor gene copy number and expression in a squamous carcinoma cell line. J. Clin. Investig. 1985, 75, 1077-1079. [CrossRef]

78. Harrison, P.T.; Vyse, S.; Huang, P.H. Rare epidermal growth factor receptor (EGFR) mutations in non-small cell lung cancer. Semin. Cancer Biol. 2020, 61, 167-179. [CrossRef]

79. Kobayashi, Y.; Mitsudomi, T. Not all epidermal growth factor receptor mutations in lung cancer are created equal: Perspectives for individualized treatment strategy. Cancer Sci. 2016, 107, 1179-1186. [CrossRef]

80. Mitsudomi, T.; Morita, S.; Yatabe, Y.; Negoro, S.; Okamoto, I.; Tsurutani, J.; Seto, T.; Satouchi, M.; Tada, H.; Hirashima, T.; et al. Gefitinib versus cisplatin plus docetaxel in patients with non-small-cell lung cancer harbouring mutations of the epidermal growth factor receptor (WJTOG3405): An open label, randomised phase 3 trial. Lancet Oncol. 2010, 11, 121-128. [CrossRef]

81. Sequist, L.V.; Yang, J.C.; Yamamoto, N.; O’Byrne, K.; Hirsh, V.; Mok, T.; Geater, S.L.; Orlov, S.; Tsai, C.M.; Boyer, M.; et al. Phase III study of afatinib or cisplatin plus pemetrexed in patients with metastatic lung adenocarcinoma with EGFR mutations. J. Clin. Oncol. 2013, 31, 3327-3334. [CrossRef] 
82. Rosell, R.; Carcereny, E.; Gervais, R.; Vergnenegre, A.; Massuti, B.; Felip, E.; Palmero, R.; Garcia-Gomez, R.; Pallares, C.; Sanchez, J.M.; et al. Erlotinib versus standard chemotherapy as first-line treatment for European patients with advanced EGFR mutationpositive non-small-cell lung cancer (EURTAC): A multicentre, open-label, randomised phase 3 trial. Lancet Oncol. 2012, 13, 239-246. [CrossRef]

83. Wu, Y.L.; Cheng, Y.; Zhou, X.; Lee, K.H.; Nakagawa, K.; Niho, S.; Tsuji, F.; Linke, R.; Rosell, R.; Corral, J.; et al. Dacomitinib versus gefitinib as first-line treatment for patients with EGFR-mutation-positive non-small-cell lung cancer (ARCHER 1050): A randomised, open-label, phase 3 trial. Lancet Oncol. 2017, 18, 1454-1466. [CrossRef]

84. Fukuoka, M.; Yano, S.; Giaccone, G.; Tamura, T.; Nakagawa, K.; Douillard, J.Y.; Nishiwaki, Y.; Vansteenkiste, J.; Kudoh, S.; Rischin, D.; et al. Multi-institutional randomized phase II trial of gefitinib for previously treated patients with advanced non-small-cell lung cancer (The IDEAL 1 Trial) [corrected]. J. Clin. Oncol. 2003, 21, 2237-2246. [CrossRef] [PubMed]

85. Kris, M.G.; Natale, R.B.; Herbst, R.S.; Lynch, T.J., Jr.; Prager, D.; Belani, C.P.; Schiller, J.H.; Kelly, K.; Spiridonidis, H.; Sandler, A.; et al. Efficacy of gefitinib, an inhibitor of the epidermal growth factor receptor tyrosine kinase, in symptomatic patients with non-small cell lung cancer: A randomized trial. JAMA 2003, 290, 2149-2158. [CrossRef] [PubMed]

86. Miller, V.A.; Kris, M.G.; Shah, N.; Patel, J.; Azzoli, C.; Gomez, J.; Krug, L.M.; Pao, W.; Rizvi, N.; Pizzo, B.; et al. Bronchioloalveolar pathologic subtype and smoking history predict sensitivity to gefitinib in advanced non-small-cell lung cancer. J. Clin. Oncol. 2004, 22, 1103-1109. [CrossRef] [PubMed]

87. Giaccone, G. Epidermal growth factor receptor inhibitors in the treatment of non-small-cell lung cancer. J. Clin. Oncol. 2005, 23, 3235-3242. [CrossRef]

88. Kim, E.S.; Hirsh, V.; Mok, T.; Socinski, M.A.; Gervais, R.; Wu, Y.L.; Li, L.Y.; Watkins, C.L.; Sellers, M.V.; Lowe, E.S.; et al. Gefitinib versus docetaxel in previously treated non-small-cell lung cancer (INTEREST): A randomised phase III trial. Lancet 2008, 372, 1809-1818. [CrossRef]

89. Maruyama, R.; Nishiwaki, Y.; Tamura, T.; Yamamoto, N.; Tsuboi, M.; Nakagawa, K.; Shinkai, T.; Negoro, S.; Imamura, F.; Eguchi, K.; et al. Phase III study, V-15-32, of gefitinib versus docetaxel in previously treated Japanese patients with non-small-cell lung cancer. J. Clin. Oncol. 2008, 26, 4244-4252. [CrossRef]

90. Lee, D.H.; Park, K.; Kim, J.H.; Lee, J.S.; Shin, S.W.; Kang, J.H.; Ahn, M.J.; Ahn, J.S.; Suh, C.; Kim, S.W. Randomized Phase III trial of gefitinib versus docetaxel in non-small cell lung cancer patients who have previously received platinum-based chemotherapy. Clin. Cancer Res. 2010, 16, 1307-1314. [CrossRef]

91. Ciuleanu, T.; Stelmakh, L.; Cicenas, S.; Miliauskas, S.; Grigorescu, A.C.; Hillenbach, C.; Johannsdottir, H.K.; Klughammer, B.; Gonzalez, E.E. Efficacy and safety of erlotinib versus chemotherapy in second-line treatment of patients with advanced, non-small-cell lung cancer with poor prognosis (TITAN): A randomised multicentre, open-label, phase 3 study. Lancet Oncol. 2012, 13, 300-308. [CrossRef]

92. Massarelli, E.; Johnson, F.M.; Erickson, H.S.; Wistuba, I.I.; Papadimitrakopoulou, V. Uncommon Epidermal Growth Factor Receptor mutations in non-small cell lung cancer and their mechanisms of EGFR tyrosine kinase inhibitors sensitivity and resistance. Lung Cancer 2013, 80, 235-241. [CrossRef]

93. Lynch, T.J.; Bell, D.W.; Sordella, R.; Gurubhagavatula, S.; Okimoto, R.A.; Brannigan, B.W.; Harris, P.L.; Haserlat, S.M.; Supko, J.G.; Haluska, F.G. Activating mutations in the epidermal growth factor receptor underlying responsiveness of non-small-cell lung cancer to gefitinib. N. Engl. J. Med. 2004, 350, 2129-2139. [CrossRef]

94. Paez, J.G.; Jänne, P.A.; Lee, J.C.; Tracy, S.; Greulich, H.; Gabriel, S.; Herman, P.; Kaye, F.J.; Lindeman, N.; Boggon, T.J. EGFR mutations in lung cancer: Correlation with clinical response to gefitinib therapy. Science 2004, 304, 1497-1500. [CrossRef] [PubMed]

95. Mok, T.S.; Wu, Y.L.; Thongprasert, S.; Yang, C.H.; Chu, D.T.; Saijo, N.; Sunpaweravong, P.; Han, B.; Margono, B.; Ichinose, Y.; et al. Gefitinib or carboplatin-paclitaxel in pulmonary adenocarcinoma. N. Engl. J. Med. 2009, 361, 947-957. [CrossRef]

96. Han, J.Y.; Park, K.; Kim, S.W.; Lee, D.H.; Kim, H.Y.; Kim, H.T.; Ahn, M.J.; Yun, T.; Ahn, J.S.; Suh, C.; et al. First-SIGNAL: First-line single-agent iressa versus gemcitabine and cisplatin trial in never-smokers with adenocarcinoma of the lung. J. Clin. Oncol. 2012, 30, 1122-1128. [CrossRef]

97. Maemondo, M.; Inoue, A.; Kobayashi, K.; Sugawara, S.; Oizumi, S.; Isobe, H.; Gemma, A.; Harada, M.; Yoshizawa, H.; Kinoshita, I.; et al. Gefitinib or chemotherapy for non-small-cell lung cancer with mutated EGFR. N. Engl. J. Med. 2010, 362, 2380-2388. [CrossRef]

98. Zhou, C.; Wu, Y.L.; Chen, G.; Feng, J.; Liu, X.Q.; Wang, C.; Zhang, S.; Wang, J.; Zhou, S.; Ren, S.; et al. Erlotinib versus chemotherapy as first-line treatment for patients with advanced EGFR mutation-positive non-small-cell lung cancer (OPTIMAL, CTONG-0802): A multicentre, open-label, randomised, phase 3 study. Lancet Oncol. 2011, 12, 735-742. [CrossRef]

99. Wu, Y.L.; Zhou, C.; Hu, C.P.; Feng, J.; Lu, S.; Huang, Y.; Li, W.; Hou, M.; Shi, J.H.; Lee, K.Y.; et al. Afatinib versus cisplatin plus gemcitabine for first-line treatment of Asian patients with advanced non-small-cell lung cancer harbouring EGFR mutations (LUX-Lung 6): An open-label, randomised phase 3 trial. Lancet Oncol. 2014, 15, 213-222. [CrossRef]

100. Gridelli, C.; Butts, C.; Ciardiello, F.; Feld, R.; Gallo, C.; Perrone, F. An international, multicenter, randomized phase III study of first-line erlotinib followed by second-line cisplatin/gemcitabine versus first-line cisplatin/gemcitabine followed by second-line erlotinib in advanced non-small-cell lung cancer: Treatment rationale and protocol dynamics of the TORCH trial. Clin. Lung Cancer 2008, 9, 235-238. [CrossRef] 
101. Gridelli, C.; Ciardiello, F.; Gallo, C.; Feld, R.; Butts, C.; Gebbia, V.; Maione, P.; Morgillo, F.; Genestreti, G.; Favaretto, A.; et al. First-line erlotinib followed by second-line cisplatin-gemcitabine chemotherapy in advanced non-small-cell lung cancer: The TORCH randomized trial. J. Clin. Oncol. 2012, 30, 3002-3011. [CrossRef] [PubMed]

102. Peters, S.; Adjei, A.A.; Gridelli, C.; Reck, M.; Kerr, K.; Felip, E. Metastatic non-small-cell lung cancer (NSCLC): ESMO Clinical Practice Guidelines for diagnosis, treatment and follow-up. Ann. Oncol. 2012, 23 (Suppl. 7), vii56-vii64. [CrossRef]

103. Ettinger, D.S.; Akerley, W.; Borghaei, H.; Chang, A.C.; Cheney, R.T.; Chirieac, L.R.; D'Amico, T.A.; Demmy, T.L.; Ganti, A.K.; Govindan, R.; et al. Non-small cell lung cancer. J. Natl. Compr. Canc. Netw. 2012, 10, 1236-1271. [CrossRef]

104. Garassino, M.C.; Martelli, O.; Broggini, M.; Farina, G.; Veronese, S.; Rulli, E.; Bianchi, F.; Bettini, A.; Longo, F.; Moscetti, L.; et al. Erlotinib versus docetaxel as second-line treatment of patients with advanced non-small-cell lung cancer and wild-type EGFR tumours (TAILOR): A randomised controlled trial. Lancet Oncol. 2013, 14, 981-988. [CrossRef]

105. Inoue, A.; Suzuki, T.; Fukuhara, T.; Maemondo, M.; Kimura, Y.; Morikawa, N.; Watanabe, H.; Saijo, Y.; Nukiwa, T. Prospective phase II study of gefitinib for chemotherapy-naive patients with advanced non-small-cell lung cancer with epidermal growth factor receptor gene mutations. J. Clin. Oncol. Off. J. Am. Soc. Clin. Oncol. 2006, 24, 3340-3346. [CrossRef] [PubMed]

106. Asahina, H.; Yamazaki, K.; Kinoshita, I.; Sukoh, N.; Harada, M.; Yokouchi, H.; Ishida, T.; Ogura, S.; Kojima, T.; Okamoto, Y.; et al. A phase II trial of gefitinib as first-line therapy for advanced non-small cell lung cancer with epidermal growth factor receptor mutations. Br. J. Cancer 2006, 95, 998-1004. [CrossRef] [PubMed]

107. Sutani, A.; Nagai, Y.; Udagawa, K.; Uchida, Y.; Koyama, N.; Murayama, Y.; Tanaka, T.; Miyazawa, H.; Nagata, M.; Kanazawa, M.; et al. Gefitinib for non-small-cell lung cancer patients with epidermal growth factor receptor gene mutations screened by peptide nucleic acid-locked nucleic acid PCR clamp. Br. J. Cancer 2006, 95, 1483-1489. [CrossRef] [PubMed]

108. Yoshida, K.; Yatabe, Y.; Park, J.Y.; Shimizu, J.; Horio, Y.; Matsuo, K.; Kosaka, T.; Mitsudomi, T.; Hida, T. Prospective validation for prediction of gefitinib sensitivity by epidermal growth factor receptor gene mutation in patients with non-small cell lung cancer. J. Thorac. Oncol. 2007, 2, 22-28. [CrossRef]

109. Sunaga, N.; Tomizawa, Y.; Yanagitani, N.; Iijima, H.; Kaira, K.; Shimizu, K.; Tanaka, S.; Suga, T.; Hisada, T.; Ishizuka, T.; et al. Phase II prospective study of the efficacy of gefitinib for the treatment of stage III/IV non-small cell lung cancer with EGFR mutations, irrespective of previous chemotherapy. Lung Cancer 2007, 56, 383-389. [CrossRef]

110. Tamura, K.; Okamoto, I.; Kashii, T.; Negoro, S.; Hirashima, T.; Kudoh, S.; Ichinose, Y.; Ebi, N.; Shibata, K.; Nishimura, T.; et al. Multicentre prospective phase II trial of gefitinib for advanced non-small cell lung cancer with epidermal growth factor receptor mutations: Results of the West Japan Thoracic Oncology Group trial (WJTOG0403). Br. J. Cancer 2008, 98, 907-914. [CrossRef]

111. Sequist, L.V.; Martins, R.G.; Spigel, D.; Grunberg, S.M.; Spira, A.; Jänne, P.A.; Joshi, V.A.; McCollum, D.; Evans, T.L.; Muzikansky, A.; et al. First-line gefitinib in patients with advanced non-small-cell lung cancer harboring somatic EGFR mutations. J. Clin. Oncol. Off. J. Am. Soc. Clin. Oncol. 2008, 26, 2442-2449. [CrossRef]

112. Paz-Ares, L.; Sanchez, J.; Garcia-Velasco, A.; Massuti, B.; Lopez-Vivanco, G.; Provencio, M.; Montes, A.; Isla, D.; Amador, M.; Rosell, R.J.J.O.C.O. A prospective phase II trial of erlotinib in advanced non-small cell lung cancer (NSCLC) patients (p) with mutations in the tyrosine kinase (TK) domain of the epidermal growth factor receptor (EGFR). J. Clin. Oncol. 2006, 24, 7020. [CrossRef]

113. Porta, R.; Queralt, C.; Cardenal, F.; Mayo, C.; Provencio, M.; Camps, C.; Isla, D.; González-Larriba, J.; Tarón, M.; Rosell, R.J.J.O.C.O. Erlotinib customization based on epidermal growth factor receptor (EGFR) mutations in stage IV non-small-cell lung cancer (NSCLC) patients (p). J. Clin. Oncol. 2008, 26, 8038. [CrossRef]

114. Costa, D.B.; Kobayashi, S.; Tenen, D.G.; Huberman, M.S. Pooled analysis of the prospective trials of gefitinib monotherapy for EGFR-mutant non-small cell lung cancers. Lung Cancer 2007, 58, 95-103. [CrossRef]

115. Ahn, M.J.; Tsai, C.M.; Shepherd, F.A.; Bazhenova, L.; Sequist, L.V.; Hida, T.; Yang, J.C.H.; Ramalingam, S.S.; Mitsudomi, T.; Jänne, P.A.; et al. Osimertinib in patients with T790M mutation-positive, advanced non-small cell lung cancer: Long-term follow-up from a pooled analysis of 2 phase 2 studies. Cancer 2019, 125, 892-901. [CrossRef]

116. Hata, A.N.; Niederst, M.J.; Archibald, H.L.; Gomez-Caraballo, M.; Siddiqui, F.M.; Mulvey, H.E.; Maruvka, Y.E.; Ji, F.; Bhang, H.E.; Krishnamurthy Radhakrishna, V.; et al. Tumor cells can follow distinct evolutionary paths to become resistant to epidermal growth factor receptor inhibition. Nat. Med. 2016, 22, 262-269. [CrossRef]

117. Ikeda, K.; Nomori, H.; Mori, T.; Sasaki, J.; Kobayashi, T. Novel germline mutation: EGFR V843I in patient with multiple lung adenocarcinomas and family members with lung cancer. Ann. Thorac. Surg. 2008, 85, 1430-1432. [CrossRef] [PubMed]

118. Ohtsuka, K.; Ohnishi, H.; Kurai, D.; Matsushima, S.; Morishita, Y.; Shinonaga, M.; Goto, H.; Watanabe, T. Familial lung adenocarcinoma caused by the EGFR V843I germ-line mutation. J. Clin. Oncol. Off. J. Am. Soc. Clin. Oncol. 2011, 29, e191-e192. [CrossRef]

119. Demierre, N.; Zoete, V.; Michielin, O.; Stauffer, E.; Zimmermann, D.R.; Betticher, D.C.; Peters, S. A dramatic lung cancer course in a patient with a rare EGFR germline mutation exon 21 V843I: Is EGFR TKI resistance predictable? Lung Cancer 2013, 80, 81-84. [CrossRef]

120. Matsushima, S.; Ohtsuka, K.; Ohnishi, H.; Fujiwara, M.; Nakamura, H.; Morii, T.; Kishino, T.; Goto, H.; Watanabe, T. V843I, a lung cancer predisposing EGFR mutation, is responsible for resistance to EGFR tyrosine kinase inhibitors. J. Thorac. Oncol. 2014, 9, 1377-1384. [CrossRef] 
121. Nakagawa, T.; Takeuchi, S.; Yamada, T.; Ebi, H.; Sano, T.; Nanjo, S.; Ishikawa, D.; Sato, M.; Hasegawa, Y.; Sekido, Y.; et al. EGFR-TKI resistance due to BIM polymorphism can be circumvented in combination with HDAC inhibition. Cancer Res. 2013, 73, 2428-2434. [CrossRef] [PubMed]

122. Costa, C.; Molina, M.A.; Drozdowskyj, A.; Giménez-Capitán, A.; Bertran-Alamillo, J.; Karachaliou, N.; Gervais, R.; Massuti, B.; Wei, J.; Moran, T.; et al. The impact of EGFR T790M mutations and BIM mRNA expression on outcome in patients with EGFR-mutant NSCLC treated with erlotinib or chemotherapy in the randomized phase III EURTAC trial. Clin. Cancer Res. 2014, 20, 2001-2010. [CrossRef] [PubMed]

123. Costa, D.B.; Halmos, B.; Kumar, A.; Schumer, S.T.; Huberman, M.S.; Boggon, T.J.; Tenen, D.G.; Kobayashi, S. BIM mediates EGFR tyrosine kinase inhibitor-induced apoptosis in lung cancers with oncogenic EGFR mutations. PLoS Med. 2007, 4, 1669-1679, discussion 1680. [CrossRef] [PubMed]

124. Cragg, M.S.; Kuroda, J.; Puthalakath, H.; Huang, D.C.; Strasser, A. Gefitinib-induced killing of NSCLC cell lines expressing mutant EGFR requires BIM and can be enhanced by BH3 mimetics. PLoS Med. 2007, 4, 1681-1689, discussion 1690. [CrossRef] [PubMed]

125. Gong, Y.; Somwar, R.; Politi, K.; Balak, M.; Chmielecki, J.; Jiang, X.; Pao, W. Induction of BIM is essential for apoptosis triggered by EGFR kinase inhibitors in mutant EGFR-dependent lung adenocarcinomas. PLoS Med. 2007, 4, e294. [CrossRef]

126. Faber, A.C.; Corcoran, R.B.; Ebi, H.; Sequist, L.V.; Waltman, B.A.; Chung, E.; Incio, J.; Digumarthy, S.R.; Pollack, S.F.; Song, Y.; et al. BIM expression in treatment-naive cancers predicts responsiveness to kinase inhibitors. Cancer Discov. 2011, 1, 352-365. [CrossRef]

127. Takezawa, K.; Okamoto, I.; Nishio, K.; Jänne, P.A.; Nakagawa, K. Role of ERK-BIM and STAT3-Survivin Signaling Pathways in ALK Inhibitor-Induced Apoptosis in EML4-ALK-Positive Lung Cancer. Clin. Cancer Res. 2011, 17, 2140. [CrossRef]

128. Leventakos, K.; Kipp, B.R.; Rumilla, K.M.; Winters, J.L.; Yi, E.S.; Mansfield, A.S. S768I Mutation in EGFR in Patients with Lung Cancer. J. Thorac. Oncol. 2016, 11, 1798-1801. [CrossRef]

129. Balak, M.N.; Gong, Y.; Riely, G.J.; Somwar, R.; Li, A.R.; Zakowski, M.F.; Chiang, A.; Yang, G.; Ouerfelli, O.; Kris, M.G.; et al. Novel D761Y and common secondary T790M mutations in epidermal growth factor receptor-mutant lung adenocarcinomas with acquired resistance to kinase inhibitors. Clin. Cancer Res. 2006, 12, 6494-6501. [CrossRef]

130. Toyooka, S.; Date, H.; Uchida, A.; Kiura, K.; Takata, M. The epidermal growth factor receptor D761Y mutation and effect of tyrosine kinase inhibitor. Clin. Cancer Res. 2007, 13, 3431, author reply 3431-3432. [CrossRef]

131. Bean, J.; Riely, G.J.; Balak, M.; Marks, J.L.; Ladanyi, M.; Miller, V.A.; Pao, W. Acquired resistance to epidermal growth factor receptor kinase inhibitors associated with a novel T854A mutation in a patient with EGFR-mutant lung adenocarcinoma. Clin. Cancer Res. 2008, 14, 7519-7525. [CrossRef] [PubMed]

132. Liang, S.-K.; Ko, J.-C.; Yang, J.C.-H.; Shih, J.-Y. Afatinib is effective in the treatment of lung adenocarcinoma with uncommon EGFR p.L747P and p.L747S mutations. Lung Cancer 2019, 133, 103-109. [CrossRef] [PubMed]

133. Chiba, M.; Togashi, Y.; Bannno, E.; Kobayashi, Y.; Nakamura, Y.; Hayashi, H.; Terashima, M.; De Velasco, M.A.; Sakai, K.; Fujita, Y.; et al. Efficacy of irreversible EGFR-TKIs for the uncommon secondary resistant EGFR mutations L747S, D761Y, and T854A. BMC Cancer 2017, 17, 281. [CrossRef] [PubMed]

134. Yu, H.A.; Arcila, M.E.; Rekhtman, N.; Sima, C.S.; Zakowski, M.F.; Pao, W.; Kris, M.G.; Miller, V.A.; Ladanyi, M.; Riely, G.J. Analysis of tumor specimens at the time of acquired resistance to EGFR-TKI therapy in 155 patients with EGFR-mutant lung cancers. Clin. Cancer Res. 2013, 19, 2240-2247. [CrossRef] [PubMed]

135. Oxnard, G.R.; Arcila, M.E.; Chmielecki, J.; Ladanyi, M.; Miller, V.A.; Pao, W. New strategies in overcoming acquired resistance to epidermal growth factor receptor tyrosine kinase inhibitors in lung cancer. Clin. Cancer Res. 2011, 17, 5530-5537. [CrossRef]

136. Tu, H.Y.; Ke, E.E.; Yang, J.J.; Sun, Y.L.; Yan, H.H.; Zheng, M.Y.; Bai, X.Y.; Wang, Z.; Su, J.; Chen, Z.H.; et al. A comprehensive review of uncommon EGFR mutations in patients with non-small cell lung cancer. Lung Cancer 2017, 114, 96-102. [CrossRef]

137. Kuiper, J.L.; Hashemi, S.M.; Thunnissen, E.; Snijders, P.J.; Grünberg, K.; Bloemena, E.; Sie, D.; Postmus, P.E.; Heideman, D.A.; Smit, E.F. Non-classic EGFR mutations in a cohort of Dutch EGFR-mutated NSCLC patients and outcomes following EGFR-TKI treatment. Br. J. Cancer 2016, 115, 1504-1512. [CrossRef]

138. Wang, F.; Li, C.; Wu, Q.; Lu, H.J.T.C.R. EGFR exon 20 insertion mutations in non-small cell lung cancer. Transl. Cancer Res. 2020, 9 , 2982-2991. [CrossRef]

139. Papadimitrakopoulou, V.; Wu, Y.-L.; Han, J.-Y.; Ahn, M.-J.; Ramalingam, S.; John, T.; Okamoto, I.; Yang, J.-H.; Bulusu, K.; Laus, G.J.A.O.O. Analysis of resistance mechanisms to osimertinib in patients with EGFR T790M advanced NSCLC from the AURA3 study. Ann. Oncol. 2018, 29, viii741. [CrossRef]

140. Zhou, T.; Zhou, X.; Li, P.; Qi, C.; Ling, Y.J.J.O.T.D. EGFR L747P mutation in one lung adenocarcinoma patient responded to afatinib treatment: A case report. J. Thorac. Dis. 2018, 10, E802-E805. [CrossRef]

141. Huang, J.; Wang, Y.; Zhai, Y.; Wang, J. Non-small cell lung cancer harboring a rare EGFR L747P mutation showing intrinsic resistance to both gefitinib and osimertinib (AZD9291): A case report. Thorac. Cancer 2018, 9, 745-749. [CrossRef]

142. Ercan, D.; Zejnullahu, K.; Yonesaka, K.; Xiao, Y.; Capelletti, M.; Rogers, A.; Lifshits, E.; Brown, A.; Lee, C.; Christensen, J.G.; et al. Amplification of EGFR T790M causes resistance to an irreversible EGFR inhibitor. Oncogene 2010, 29, 2346-2356. [CrossRef]

143. Thress, K.S.; Paweletz, C.P.; Felip, E.; Cho, B.C.; Stetson, D.; Dougherty, B.; Lai, Z.; Markovets, A.; Vivancos, A.; Kuang, Y.; et al. Acquired EGFR C797S mutation mediates resistance to AZD9291 in non-small cell lung cancer harboring EGFR T790M. Nat. Med. 2015, 21, 560-562. [CrossRef]

144. Jia, Y.; Yun, C.H.; Park, E.; Ercan, D.; Manuia, M.; Juarez, J.; Xu, C.; Rhee, K.; Chen, T.; Zhang, H.; et al. Overcoming EGFR(T790M) and EGFR(C797S) resistance with mutant-selective allosteric inhibitors. Nature 2016, 534, 129-132. [CrossRef] 
145. Yang, Z.; Yang, N.; Ou, Q.; Xiang, Y.; Jiang, T.; Wu, X.; Bao, H.; Tong, X.; Wang, X.; Shao, Y.W.; et al. Investigating Novel Resistance Mechanisms to Third-Generation EGFR Tyrosine Kinase Inhibitor Osimertinib in Non-Small Cell Lung Cancer Patients. Clin. Cancer Res. 2018, 24, 3097-3107. [CrossRef]

146. Zheng, D.; Hu, M.; Bai, Y.; Zhu, X.; Lu, X.; Wu, C.; Wang, J.; Liu, L.; Wang, Z.; Ni, J.; et al. EGFR G796D mutation mediates resistance to osimertinib. Oncotarget 2017, 8, 49671-49679. [CrossRef]

147. Chen, K.; Zhou, F.; Shen, W.; Jiang, T.; Wu, X.; Tong, X.; Shao, Y.W.; Qin, S.; Zhou, C. Novel Mutations on EGFR Leu792 Potentially Correlate to Acquired Resistance to Osimertinib in Advanced NSCLC. J. Thorac. Oncol. 2017, 12, e65-e68. [CrossRef]

148. Bersanelli, M.; Minari, R.; Bordi, P.; Gnetti, L.; Bozzetti, C.; Squadrilli, A.; Lagrasta, C.A.; Bottarelli, L.; Osipova, G.; Capelletto, E.; et al. L718Q Mutation as New Mechanism of Acquired Resistance to AZD9291 in EGFR-Mutated NSCLC. J. Thorac. Oncol. 2016, 11, e121-e123. [CrossRef]

149. Fassunke, J.; Müller, F.; Keul, M.; Michels, S.; Dammert, M.A.; Schmitt, A.; Plenker, D.; Lategahn, J.; Heydt, C.; Brägelmann, J.; et al. Overcoming EGFRG724S-mediated osimertinib resistance through unique binding characteristics of second-generation EGFR inhibitors. Nat. Commun. 2018, 9, 4655. [CrossRef]

150. Leonetti, A.; Sharma, S.; Minari, R.; Perego, P.; Giovannetti, E.; Tiseo, M. Resistance mechanisms to osimertinib in EGFR-mutated non-small cell lung cancer. Br. J. Cancer 2019, 121, 725-737. [CrossRef]

151. Suda, K.; Mizuuchi, H.; Murakami, I.; Uramoto, H.; Tanaka, F.; Sato, K.; Takemoto, T.; Iwasaki, T.; Sekido, Y.; Yatabe, Y.; et al. CRKL amplification is rare as a mechanism for acquired resistance to kinase inhibitors in lung cancers with epidermal growth factor receptor mutation. Lung Cancer 2014, 85, 147-151. [CrossRef] [PubMed]

152. Cheung, H.W.; Du, J.; Boehm, J.S.; He, F.; Weir, B.A.; Wang, X.; Butaney, M.; Sequist, L.V.; Luo, B.; Engelman, J.A.; et al. Amplification of CRKL induces transformation and epidermal growth factor receptor inhibitor resistance in human non-small cell lung cancers. Cancer Discov. 2011, 1, 608-625. [CrossRef] [PubMed]

153. Ercan, D.; Xu, C.; Yanagita, M.; Monast, C.S.; Pratilas, C.A.; Montero, J.; Butaney, M.; Shimamura, T.; Sholl, L.; Ivanova, E.V.; et al. Reactivation of ERK signaling causes resistance to EGFR kinase inhibitors. Cancer Discov. 2012, 2, 934-947. [CrossRef] [PubMed]

154. Guix, M.; Faber, A.C.; Wang, S.E.; Olivares, M.G.; Song, Y.; Qu, S.; Rinehart, C.; Seidel, B.; Yee, D.; Arteaga, C.L.; et al. Acquired resistance to EGFR tyrosine kinase inhibitors in cancer cells is mediated by loss of IGF-binding proteins. J. Clin. Investig. 2008, 118, 2609-2619. [CrossRef]

155. Cortot, A.B.; Repellin, C.E.; Shimamura, T.; Capelletti, M.; Zejnullahu, K.; Ercan, D.; Christensen, J.G.; Wong, K.K.; Gray, N.S.; Jänne, P.A. Resistance to irreversible EGF receptor tyrosine kinase inhibitors through a multistep mechanism involving the IGF1R pathway. Cancer Res. 2013, 73, 834-843. [CrossRef]

156. Engelman, J.A.; Zejnullahu, K.; Mitsudomi, T.; Song, Y.; Hyland, C.; Park, J.O.; Lindeman, N.; Gale, C.M.; Zhao, X.; Christensen, J.; et al. MET amplification leads to gefitinib resistance in lung cancer by activating ERBB3 signaling. Science 2007, 316, 1039-1043. [CrossRef]

157. Ortiz-Cuaran, S.; Scheffler, M.; Plenker, D.; Dahmen, L.; Scheel, A.H.; Fernandez-Cuesta, L.; Meder, L.; Lovly, C.M.; Persigehl, T.; Merkelbach-Bruse, S.; et al. Heterogeneous Mechanisms of Primary and Acquired Resistance to Third-Generation EGFR Inhibitors. Clin. Cancer Res. 2016, 22, 4837-4847. [CrossRef]

158. Planchard, D.; Loriot, Y.; Andre, F.; Gobert, A.; Auger, N.; Lacroix, L.; Soria, J.C. EGFR-independent mechanisms of acquired resistance to AZD9291 in EGFR T790M-positive NSCLC patients. Ann. Oncol. 2015, 26, 2073-2078. [CrossRef]

159. Takezawa, K.; Pirazzoli, V.; Arcila, M.E.; Nebhan, C.A.; Song, X.; de Stanchina, E.; Ohashi, K.; Janjigian, Y.Y.; Spitzler, P.J.; Melnick, M.A.; et al. HER2 amplification: A potential mechanism of acquired resistance to EGFR inhibition in EGFR-mutant lung cancers that lack the second-site EGFRT790M mutation. Cancer Discov. 2012, 2, 922-933. [CrossRef]

160. Piotrowska, Z.; Thress, K.S.; Mooradian, M.; Heist, R.S.; Azzoli, C.G.; Temel, J.S.; Rizzo, C.; Nagy, R.J.; Lanman, R.B.; Gettinger, S.N.; et al. MET amplification (amp) as a resistance mechanism to osimertinib. J. Clin. Oncol. 2017, 35, 9020. [CrossRef]

161. Xu, J.; Wang, J.; Zhang, S. Mechanisms of resistance to irreversible epidermal growth factor receptor tyrosine kinase inhibitors and therapeutic strategies in non-small cell lung cancer. Oncotarget 2017, 8, 90557-90578. [CrossRef]

162. Tan, D.S.-W.; Kim, D.-W.; Leighl, N.B.; Riely, G.J.; Yang, J.C.-H.; Wolf, J.; Seto, T.; Felip, E.; Aix, S.P.; Jonnaert, M.; et al. Genomic profiling of resistant tumor samples following progression on EGF816, a third generation, mutant-selective EGFR tyrosine kinase inhibitor (TKI), in advanced non-small cell lung cancer (NSCLC). J. Clin. Oncol. 2017, 35, 11506. [CrossRef]

163. Sos, M.L.; Koker, M.; Weir, B.A.; Heynck, S.; Rabinovsky, R.; Zander, T.; Seeger, J.M.; Weiss, J.; Fischer, F.; Frommolt, P.; et al. PTEN loss contributes to erlotinib resistance in EGFR-mutant lung cancer by activation of Akt and EGFR. Cancer Res. 2009, 69, 3256-3261. [CrossRef]

164. Tan, D.S.-W.; Lim, K.H.; Tai, W.M.; Ahmad, A.; Pan, S.; Ng, Q.S.; Ang, M.-K.; Gogna, A.; Ng, Y.L.; Tan, B.S.; et al. A phase Ib safety and tolerability study of a pan class I PI3K inhibitor buparlisib (BKM120) and gefitinib (gef) in EGFR TKI-resistant NSCLC. J. Clin. Oncol. 2013, 31, 8107. [CrossRef]

165. Fang, W.; Huang, Y.; Gu, W.; Gan, J.; Wang, W.; Zhang, S.; Wang, K.; Zhan, J.; Yang, Y.; Huang, Y.; et al. PI3K-AKT-mTOR pathway alterations in advanced NSCLC patients after progression on EGFR-TKI and clinical response to EGFR-TKI plus everolimus combination therapy. Transl. Lung Cancer Res. 2020, 9, 1258-1267. [CrossRef]

166. Ho, C.C.; Liao, W.Y.; Lin, C.A.; Shih, J.Y.; Yu, C.J.; Yang, J.C. Acquired BRAF V600E Mutation as Resistant Mechanism after Treatment with Osimertinib. J. Thorac. Oncol. 2017, 12, 567-572. [CrossRef] 
167. Ohashi, K.; Sequist, L.V.; Arcila, M.E.; Moran, T.; Chmielecki, J.; Lin, Y.L.; Pan, Y.; Wang, L.; de Stanchina, E.; Shien, K.; et al. Lung cancers with acquired resistance to EGFR inhibitors occasionally harbor BRAF gene mutations but lack mutations in KRAS, NRAS, or MEK1. Proc. Natl. Acad. Sci. USA 2012, 109, E2127-E2133. [CrossRef]

168. Pao, W.; Wang, T.Y.; Riely, G.J.; Miller, V.A.; Pan, Q.; Ladanyi, M.; Zakowski, M.F.; Heelan, R.T.; Kris, M.G.; Varmus, H.E. KRAS mutations and primary resistance of lung adenocarcinomas to gefitinib or erlotinib. PLoS Med. 2005, 2, e17. [CrossRef]

169. Zhang, Z.; Lee, J.C.; Lin, L.; Olivas, V.; Au, V.; LaFramboise, T.; Abdel-Rahman, M.; Wang, X.; Levine, A.D.; Rho, J.K.; et al. Activation of the AXL kinase causes resistance to EGFR-targeted therapy in lung cancer. Nat. Genet. 2012, 44, 852-860. [CrossRef]

170. Sequist, L.V.; Waltman, B.A.; Dias-Santagata, D.; Digumarthy, S.; Turke, A.B.; Fidias, P.; Bergethon, K.; Shaw, A.T.; Gettinger, S.; Cosper, A.K.; et al. Genotypic and histological evolution of lung cancers acquiring resistance to EGFR inhibitors. Sci. Transl. Med. 2011, 3, 75ra26. [CrossRef]

171. Ham, J.S.; Kim, S.; Kim, H.K.; Byeon, S.; Sun, J.M.; Lee, S.H.; Ahn, J.S.; Park, K.; Choi, Y.L.; Han, J.; et al. Two Cases of Small Cell Lung Cancer Transformation from EGFR Mutant Adenocarcinoma During AZD9291 Treatment. J. Thorac. Oncol. 2016, 11, e1-e4. [CrossRef]

172. Levin, P.A.; Mayer, M.; Hoskin, S.; Sailors, J.; Oliver, D.H.; Gerber, D.E. Histologic Transformation from Adenocarcinoma to Squamous Cell Carcinoma as a Mechanism of Resistance to EGFR Inhibition. J. Thorac. Oncol. 2015, 10, e86-e88. [CrossRef]

173. Scher, K.S.; Saldivar, J.S.; Fishbein, M.; Marchevsky, A.; Reckamp, K.L. EGFR-mutated lung cancer with T790M-acquired resistance in the brain and histologic transformation in the lung. J. Natl. Compr. Cancer Netw. JNCCN 2013, 11, 1040-1044. [CrossRef]

174. Schoenfeld, A.J.; Chan, J.M.; Rizvi, H.; Rekhtman, N.; Daneshbod, Y.; Kubota, D.; Chang, J.C.; Arcila, M.E.; Ladanyi, M.; Somwar, R.; et al. Tissue-based molecular and histological landscape of acquired resistance to osimertinib given initially or at relapse in patients with EGFR-mutant lung cancers. J. Clin. Oncol. 2019, 37, 9028. [CrossRef]

175. Bivona, T.G.; Hieronymus, H.; Parker, J.; Chang, K.; Taron, M.; Rosell, R.; Moonsamy, P.; Dahlman, K.; Miller, V.A.; Costa, C.; et al. FAS and NF- $\mathrm{BB}$ signalling modulate dependence of lung cancers on mutant EGFR. Nature 2011, 471, 523-526. [CrossRef]

176. Li, B.; Ren, S.; Li, X.; Wang, Y.; Garfield, D.; Zhou, S.; Chen, X.; Su, C.; Chen, M.; Kuang, P.; et al. MiR-21 overexpression is associated with acquired resistance of EGFR-TKI in non-small cell lung cancer. Lung Cancer 2014, 83, 146-153. [CrossRef] [PubMed]

177. Enrico, D.; Lacroix, L.; Chen, J.; Rouleau, E.; Scoazec, J.-Y.; Loriot, Y.; Tselikas, L.; Jovelet, C.; Planchard, D.; Gazzah, A.; et al. Oncogenic Fusions May Be Frequently Present at Resistance of EGFR Tyrosine Kinase Inhibitors in Patients With NSCLC: A Brief Report. JTO Clin. Res. Rep. 2020, 1, 100023. [CrossRef]

178. Xu, H.; Shen, J.; Xiang, J.; Li, H.; Li, B.; Zhang, T.; Zhang, L.; Mao, X.; Jian, H.; Shu, Y. Characterization of acquired receptor tyrosine-kinase fusions as mechanisms of resistance to EGFR tyrosine-kinase inhibitors. Cancer Manag. Res. 2019, 11, 6343-6351. [CrossRef] [PubMed]

179. Solomon, B.; Varella-Garcia, M.; Camidge, D.R. ALK gene rearrangements: A new therapeutic target in a molecularly defined subset of non-small cell lung cancer. J. Thorac. Oncol. 2009, 4, 1450-1454. [CrossRef]

180. Schrock, A.B.; Zhu, V.W.; Hsieh, W.S.; Madison, R.; Creelan, B.; Silberberg, J.; Costin, D.; Bharne, A.; Bonta, I.; Bosemani, T.; et al. Receptor Tyrosine Kinase Fusions and BRAF Kinase Fusions are Rare but Actionable Resistance Mechanisms to EGFR Tyrosine Kinase Inhibitors. J. Thorac. Oncol. 2018, 13, 1312-1323. [CrossRef] [PubMed]

181. Rich, T.A.; Reckamp, K.L.; Chae, Y.K.; Doebele, R.C.; Iams, W.T.; Oh, M.; Raymond, V.M.; Lanman, R.B.; Riess, J.W.; Stinchcombe, T.E.; et al. Analysis of Cell-Free DNA from 32,989 Advanced Cancers Reveals Novel Co-occurring Activating RET Alterations and Oncogenic Signaling Pathway Aberrations. Clin. Cancer Res. 2019, 25, 5832-5842. [CrossRef]

182. Kobayashi, S.; Boggon, T.J.; Dayaram, T.; Jänne, P.A.; Kocher, O.; Meyerson, M.; Johnson, B.E.; Eck, M.J.; Tenen, D.G.; Halmos, B. EGFR mutation and resistance of non-small-cell lung cancer to gefitinib. N. Engl. J. Med. 2005, 352, 786-792. [CrossRef]

183. Pao, W.; Miller, V.A.; Politi, K.A.; Riely, G.J.; Somwar, R.; Zakowski, M.F.; Kris, M.G.; Varmus, H. Acquired resistance of lung adenocarcinomas to gefitinib or erlotinib is associated with a second mutation in the EGFR kinase domain. PLoS Med. 2005, 2, e73. [CrossRef]

184. Riely, G.J.; Pao, W.; Pham, D.; Li, A.R.; Rizvi, N.; Venkatraman, E.S.; Zakowski, M.F.; Kris, M.G.; Ladanyi, M.; Miller, V.A. Clinical course of patients with non-small cell lung cancer and epidermal growth factor receptor exon 19 and exon 21 mutations treated with gefitinib or erlotinib. Clin. Cancer Res. 2006, 12, 839-844. [CrossRef]

185. Chmielecki, J.; Foo, J.; Oxnard, G.R.; Hutchinson, K.; Ohashi, K.; Somwar, R.; Wang, L.; Amato, K.R.; Arcila, M.; Sos, M.L.; et al. Optimization of dosing for EGFR-mutant non-small cell lung cancer with evolutionary cancer modeling. Sci. Transl. Med. 2011, 3, 90ra59. [CrossRef]

186. Lim, S.M.; Syn, N.L.; Cho, B.C.; Soo, R.A. Acquired resistance to EGFR targeted therapy in non-small cell lung cancer: Mechanisms and therapeutic strategies. Cancer Treat. Rev. 2018, 65, 1-10. [CrossRef]

187. Maheswaran, S.; Sequist, L.V.; Nagrath, S.; Ulkus, L.; Brannigan, B.; Collura, C.V.; Inserra, E.; Diederichs, S.; Iafrate, A.J.; Bell, D.W.; et al. Detection of mutations in EGFR in circulating lung-cancer cells. N. Engl. J. Med. 2008, 359, 366-377. [CrossRef]

188. Toyooka, S.; Kiura, K.; Mitsudomi, T. EGFR mutation and response of lung cancer to gefitinib. N. Engl. J. Med. 2005, 352, 2136, author reply 2136. [CrossRef]

189. Bell, D.W.; Gore, I.; Okimoto, R.A.; Godin-Heymann, N.; Sordella, R.; Mulloy, R.; Sharma, S.V.; Brannigan, B.W.; Mohapatra, G.; Settleman, J.; et al. Inherited susceptibility to lung cancer may be associated with the T790M drug resistance mutation in EGFR. Nat. Genet. 2005, 37, 1315-1316. [CrossRef] 
190. Mulloy, R.; Ferrand, A.; Kim, Y.; Sordella, R.; Bell, D.W.; Haber, D.A.; Anderson, K.S.; Settleman, J. Epidermal growth factor receptor mutants from human lung cancers exhibit enhanced catalytic activity and increased sensitivity to gefitinib. Cancer Res. 2007, 67, 2325-2330. [CrossRef]

191. Settleman, J.; Kurie, J.M. Drugging the bad "AKT-TOR" to overcome TKI-resistant lung cancer. Cancer Cell 2007, 12, 6-8. [CrossRef] [PubMed]

192. Suda, K.; Onozato, R.; Yatabe, Y.; Mitsudomi, T. EGFR T790M mutation: A double role in lung cancer cell survival? J. Thorac. Oncol. 2009, 4, 1-4. [CrossRef] [PubMed]

193. Yun, C.H.; Mengwasser, K.E.; Toms, A.V.; Woo, M.S.; Greulich, H.; Wong, K.K.; Meyerson, M.; Eck, M.J. The T790M mutation in EGFR kinase causes drug resistance by increasing the affinity for ATP. Proc. Natl. Acad. Sci. USA 2008, 105, $2070-2075$. [CrossRef] [PubMed]

194. Thatcher, N.; Chang, A.; Parikh, P.; Rodrigues Pereira, J.; Ciuleanu, T.; von Pawel, J.; Thongprasert, S.; Tan, E.H.; Pemberton, K.; Archer, V.; et al. Gefitinib plus best supportive care in previously treated patients with refractory advanced non-small-cell lung cancer: Results from a randomised, placebo-controlled, multicentre study (Iressa Survival Evaluation in Lung Cancer). Lancet (Lond. Engl.) 2005, 366, 1527-1537. [CrossRef]

195. Miller, V.A.; Hirsh, V.; Cadranel, J.; Chen, Y.M.; Park, K.; Kim, S.W.; Zhou, C.; Su, W.C.; Wang, M.; Sun, Y.; et al. Afatinib versus placebo for patients with advanced, metastatic non-small-cell lung cancer after failure of erlotinib, gefitinib, or both, and one or two lines of chemotherapy (LUX-Lung 1): A phase 2b/3 randomised trial. Lancet Oncol. 2012, 13, 528-538. [CrossRef]

196. Li, D.; Ambrogio, L.; Shimamura, T.; Kubo, S.; Takahashi, M.; Chirieac, L.R.; Padera, R.F.; Shapiro, G.I.; Baum, A.; Himmelsbach, F.; et al. BIBW2992, an irreversible EGFR/HER2 inhibitor highly effective in preclinical lung cancer models. Oncogene 2008, 27, 4702-4711. [CrossRef]

197. Mok, T.S.; Wu, Y.L.; Ahn, M.J.; Garassino, M.C.; Kim, H.R.; Ramalingam, S.S.; Shepherd, F.A.; He, Y.; Akamatsu, H.; Theelen, W.S.; et al. Osimertinib or Platinum-Pemetrexed in EGFR T790M-Positive Lung Cancer. N. Engl. J. Med. 2017, 376, 629-640. [CrossRef]

198. Soria, J.C.; Ohe, Y.; Vansteenkiste, J.; Reungwetwattana, T.; Chewaskulyong, B.; Lee, K.H.; Dechaphunkul, A.; Imamura, F.; Nogami, N.; Kurata, T.; et al. Osimertinib in Untreated EGFR-Mutated Advanced Non-Small-Cell Lung Cancer. N. Engl. J. Med. 2018, 378, 113-125. [CrossRef]

199. Brown, B.P.; Zhang, Y.K.; Westover, D.; Yan, Y.; Qiao, H.; Huang, V.; Du, Z.; Smith, J.A.; Ross, J.S.; Miller, V.A.; et al. On-target Resistance to the Mutant-Selective EGFR Inhibitor Osimertinib Can Develop in an Allele-Specific Manner Dependent on the Original EGFR-Activating Mutation. Clin. Cancer Res. 2019, 25, 3341-3351. [CrossRef]

200. Le, X.; Puri, S.; Negrao, M.V.; Nilsson, M.B.; Robichaux, J.; Boyle, T.; Hicks, J.K.; Lovinger, K.L.; Roarty, E.; Rinsurongkawong, W.; et al. Landscape of EGFR-Dependent and -Independent Resistance Mechanisms to Osimertinib and Continuation Therapy Beyond Progression in EGFR-Mutant NSCLC. Clin. Cancer Res. 2018, 24, 6195-6203. [CrossRef]

201. Ramalingam, S.S.; Cheng, Y.; Zhou, C.; Ohe, Y.; Imamura, F.; Cho, B.C.; Lin, M.C.; Majem, M.; Shah, R.; Rukazenkov, Y.; et al. LBA50-Mechanisms of acquired resistance to first-line osimertinib: Preliminary data from the phase III FLAURA study. Ann. Oncol. 2018, 29, viii740. [CrossRef]

202. Ou, S.I.; Cui, J.; Schrock, A.B.; Goldberg, M.E.; Zhu, V.W.; Albacker, L.; Stephens, P.J.; Miller, V.A.; Ali, S.M. Emergence of novel and dominant acquired EGFR solvent-front mutations at Gly796 (G796S/R) together with C797S/R and L792F/H mutations in one EGFR (L858R/T790M) NSCLC patient who progressed on osimertinib. Lung Cancer 2017, 108, 228-231. [CrossRef]

203. Arulananda, S.; Do, H.; Musafer, A.; Mitchell, P.; Dobrovic, A.; John, T. Combination Osimertinib and Gefitinib in C797S and T790M EGFR-Mutated Non-Small Cell Lung Cancer. J. Thorac. Oncol. 2017, 12, 1728-1732. [CrossRef]

204. Wang, Z.; Yang, J.J.; Huang, J.; Ye, J.Y.; Zhang, X.C.; Tu, H.Y.; Han-Zhang, H.; Wu, Y.L. Lung Adenocarcinoma Harboring EGFR T790M and In Trans C797S Responds to Combination Therapy of First- and Third-Generation EGFR TKIs and Shifts Allelic Configuration at Resistance. J. Thorac. Oncol. 2017, 12, 1723-1727. [CrossRef]

205. Zhang, X.; Gureasko, J.; Shen, K.; Cole, P.A.; Kuriyan, J. An allosteric mechanism for activation of the kinase domain of epidermal growth factor receptor. Cell 2006, 125, 1137-1149. [CrossRef]

206. Dogruluk, T.; Tsang, Y.H.; Espitia, M.; Chen, F.; Chen, T.; Chong, Z.; Appadurai, V.; Dogruluk, A.; Eterovic, A.K.; Bonnen, P.E.; et al. Identification of Variant-Specific Functions of PIK3CA by Rapid Phenotyping of Rare Mutations. Cancer Res. 2015, 75, 5341-5354. [CrossRef]

207. Imielinski, M.; Berger, A.H.; Hammerman, P.S.; Hernandez, B.; Pugh, T.J.; Hodis, E.; Cho, J.; Suh, J.; Capelletti, M.; Sivachenko, A.; et al. Mapping the hallmarks of lung adenocarcinoma with massively parallel sequencing. Cell 2012, 150, 1107-1120. [CrossRef]

208. Sholl, L.M.; Aisner, D.L.; Varella-Garcia, M.; Berry, L.D.; Dias-Santagata, D.; Wistuba, I.I.; Chen, H.; Fujimoto, J.; Kugler, K.; Franklin, W.A.; et al. Multi-institutional Oncogenic Driver Mutation Analysis in Lung Adenocarcinoma: The Lung Cancer Mutation Consortium Experience. J. Thorac. Oncol. 2015, 10, 768-777. [CrossRef]

209. Diaz, L.A., Jr.; Williams, R.T.; Wu, J.; Kinde, I.; Hecht, J.R.; Berlin, J.; Allen, B.; Bozic, I.; Reiter, J.G.; Nowak, M.A.; et al. The molecular evolution of acquired resistance to targeted EGFR blockade in colorectal cancers. Nature 2012, 486, 537-540. [CrossRef]

210. Park, J.; Cho, Y.-H.; Shin, W.-J.; Lee, S.-K.; Lee, J.; Kim, T.; Cha, P.-H.; Yang, J.S.; Cho, J.; Min, D.S.; et al. A Ras destabilizer KYA1797K overcomes the resistance of EGFR tyrosine kinase inhibitor in KRAS-mutated non-small cell lung cancer. Sci. Rep. 2019, 9, 648. [CrossRef] 
211. Chabon, J.J.; Simmons, A.D.; Lovejoy, A.F.; Esfahani, M.S.; Newman, A.M.; Haringsma, H.J.; Kurtz, D.M.; Stehr, H.; Scherer, F.; Karlovich, C.A.; et al. Circulating tumour DNA profiling reveals heterogeneity of EGFR inhibitor resistance mechanisms in lung cancer patients. Nat. Commun. 2016, 7, 11815. [CrossRef]

212. Wang, Q.; Yang, S.; Wang, K.; Sun, S.Y. MET inhibitors for targeted therapy of EGFR TKI-resistant lung cancer. J. Hematol. Oncol. 2019, 12, 63. [CrossRef]

213. Noonan, S.A.; Berry, L.; Lu, X.; Gao, D.; Barón, A.E.; Chesnut, P.; Sheren, J.; Aisner, D.L.; Merrick, D.; Doebele, R.C.; et al. Identifying the Appropriate FISH Criteria for Defining MET Copy Number-Driven Lung Adenocarcinoma through Oncogene Overlap Analysis. J. Thorac. Oncol. 2016, 11, 1293-1304. [CrossRef]

214. Wang, Y.; Li, L.; Han, R.; Jiao, L.; Zheng, J.; He, Y. Clinical analysis by next-generation sequencing for NSCLC patients with MET amplification resistant to osimertinib. Lung Cancer 2018, 118, 105-110. [CrossRef] [PubMed]

215. Wu, Y.L.; Zhang, L.; Kim, D.W.; Liu, X.; Lee, D.H.; Yang, J.C.; Ahn, M.J.; Vansteenkiste, J.F.; Su, W.C.; Felip, E.; et al. Phase Ib/II Study of Capmatinib (INC280) Plus Gefitinib After Failure of Epidermal Growth Factor Receptor (EGFR) Inhibitor Therapy in Patients With EGFR-Mutated, MET Factor-Dysregulated Non-Small-Cell Lung Cancer. J. Clin. Oncol. Off. J. Am. Soc. Clin. Oncol. 2018, 36, 3101-3109. [CrossRef] [PubMed]

216. Turke, A.B.; Zejnullahu, K.; Wu, Y.L.; Song, Y.; Dias-Santagata, D.; Lifshits, E.; Toschi, L.; Rogers, A.; Mok, T.; Sequist, L.; et al. Preexistence and clonal selection of MET amplification in EGFR mutant NSCLC. Cancer Cell 2010, 17, 77-88. [CrossRef]

217. Yamada, T.; Matsumoto, K.; Wang, W.; Li, Q.; Nishioka, Y.; Sekido, Y.; Sone, S.; Yano, S. Hepatocyte Growth Factor Reduces Susceptibility to an Irreversible Epidermal Growth Factor Receptor Inhibitor in EGFR-T790M Mutant Lung Cancer. Clin. Cancer Res. 2010, 16, 174-183. [CrossRef]

218. Mazières, J.; Barlesi, F.; Filleron, T.; Besse, B.; Monnet, I.; Beau-Faller, M.; Peters, S.; Dansin, E.; Früh, M.; Pless, M.; et al. Lung cancer patients with HER2 mutations treated with chemotherapy and HER2-targeted drugs: Results from the European EUHER2 cohort. Ann. Oncol. 2016, 27, 281-286. [CrossRef] [PubMed]

219. Azuma, K.; Kawahara, A.; Sonoda, K.; Nakashima, K.; Tashiro, K.; Watari, K.; Izumi, H.; Kage, M.; Kuwano, M.; Ono, M.; et al. FGFR1 activation is an escape mechanism in human lung cancer cells resistant to afatinib, a pan-EGFR family kinase inhibitor. Oncotarget 2014, 5, 5908-5919. [CrossRef] [PubMed]

220. Guibert, N.M.; Paweletz, C.; Hu, Y.; Feeney, N.B.; Plagnol, V.; Poole, V.; Jones, G.; Oxnard, G.R. Early detection of competing resistance mutations using plasma next-generation sequencing (NGS) in patients (pts) with EGFR-mutant NSCLC treated with osimertinib. J. Clin. Oncol. 2017, 35, 11529. [CrossRef]

221. Sharma, S.V.; Lee, D.Y.; Li, B.; Quinlan, M.P.; Takahashi, F.; Maheswaran, S.; McDermott, U.; Azizian, N.; Zou, L.; Fischbach, M.A.; et al. A chromatin-mediated reversible drug-tolerant state in cancer cell subpopulations. Cell 2010, 141, 69-80. [CrossRef]

222. Wang, R.; Yamada, T.; Kita, K.; Taniguchi, H.; Arai, S.; Fukuda, K.; Terashima, M.; Ishimura, A.; Nishiyama, A.; Tanimoto, A.; et al. Transient IGF-1R inhibition combined with osimertinib eradicates AXL-low expressing EGFR mutated lung cancer. Nat. Commun. 2020, 11, 4607. [CrossRef]

223. Niederst, M.J.; Sequist, L.V.; Poirier, J.T.; Mermel, C.H.; Lockerman, E.L.; Garcia, A.R.; Katayama, R.; Costa, C.; Ross, K.N.; Moran, T.; et al. RB loss in resistant EGFR mutant lung adenocarcinomas that transform to small-cell lung cancer. Nat. Commun. 2015, 6, 6377. [CrossRef]

224. Jain, P.; Fierst, T.M.; Han, H.J.; Smith, T.E.; Vakil, A.; Storm, P.B.; Resnick, A.C.; Waanders, A.J. CRAF gene fusions in pediatric low-grade gliomas define a distinct drug response based on dimerization profiles. Oncogene 2017, 36, 6348-6358. [CrossRef]

225. Lin, J.J.; Zhu, V.W.; Yoda, S.; Yeap, B.Y.; Schrock, A.B.; Dagogo-Jack, I.; Jessop, N.A.; Jiang, G.Y.; Le, L.P.; Gowen, K.; et al. Impact of EML4-ALK Variant on Resistance Mechanisms and Clinical Outcomes in ALK-Positive Lung Cancer. J. Clin. Oncol. Off. J. Am. Soc. Clin. Oncol. 2018, 36, 1199-1206. [CrossRef]

226. Zahavi, D.; AlDeghaither, D.; O'Connell, A.; Weiner, L.M. Enhancing antibody-dependent cell-mediated cytotoxicity: A strategy for improving antibody-based immunotherapy. Antib. Ther. 2018, 1, 7-12. [CrossRef]

227. Pirker, R.; Pereira, J.R.; Szczesna, A.; von Pawel, J.; Krzakowski, M.; Ramlau, R.; Vynnychenko, I.; Park, K.; Yu, C.T.; Ganul, V.; et al. Cetuximab plus chemotherapy in patients with advanced non-small-cell lung cancer (FLEX): An open-label randomised phase III trial. Lancet 2009, 373, 1525-1531. [CrossRef]

228. Cho, J.; Chen, L.; Sangji, N.; Okabe, T.; Yonesaka, K.; Francis, J.M.; Flavin, R.J.; Johnson, W.; Kwon, J.; Yu, S.; et al. Cetuximab response of lung cancer-derived EGF receptor mutants is associated with asymmetric dimerization. Cancer Res 2013, 73, 6770-6779. [CrossRef]

229. Vyse, S.; Huang, P.H. Targeting EGFR exon 20 insertion mutations in non-small cell lung cancer. Signal Transduct. Target. Ther. 2019, 4, 5. [CrossRef]

230. van Veggel, B.; de Langen, A.J.; Hashemi, S.M.S.; Monkhorst, K.; Heideman, D.A.M.; Thunnissen, E.; Smit, E.F. Afatinib and Cetuximab in Four Patients With EGFR Exon 20 Insertion-Positive Advanced NSCLC. J. Thorac. Oncol. 2018, 13, 1222-1226. [CrossRef]

231. Truong, T.H.; Ung, P.M.; Palde, P.B.; Paulsen, C.E.; Schlessinger, A.; Carroll, K.S. Molecular Basis for Redox Activation of Epidermal Growth Factor Receptor Kinase. Cell Chem. Biol. 2016, 23, 837-848. [CrossRef] [PubMed]

232. Riess, J.W.; Groshen, S.G.; Reckamp, K.L.; Wakelee, H.A.; Oxnard, G.R.; Padda, S.K.; Koczywas, M.; Piotrowska, Z.; Sholl, L.M.; Paweletz, C.P.; et al. Osimertinib (Osi) plus necitumumab (Neci) in EGFR-mutant NSCLC: An ETCTN California cancer consortium phase I study. J. Clin. Oncol. 2019, 37, 9057. [CrossRef] 